\title{
ANAYASALCILIK VE DEMOKRASİ ARASINDAKİ İLIŞSİ: SÜREKLİ BİR ÇATIŞMA MI SIMBIYYOTIKK BİR BİRLİKTELİK Mİ?
}

Arş. Gör. Atıl Buğra KARADAŞ

\begin{abstract}
ÖZET
Kaynağını Antik Dünya'dan alan demokrasi, halk egemenliği düşüncesine dayanmaktadır. Öte yandan anayasalcılık teorisiyse siyasi iktidarı, kaynağı ne olursa olsun, sınırlandırmak ve kısıtlamakla ilgilenmektedir. Her ne kadar, demokrasi ve anayasalcılık arasında bir çatışma, bu iki kavramın farklı hedef ve amaçları göz önüne alınınca kaçınılmaz gözükse de; bir arada var oluşa giden bir yol da vardır. Bu yol, demokrasinin var oluşundan önce gelen gerekleri olan siyasi eşitlik ve özgürlük pusulasının yardımıyla bulunabilir. Zira insan tecrübesinin gösterdiği gibi, halk yığınları ve onların temsilcileri de mutlak krallar kadar tiranlığa yatkın olabilmektedir. Dahası anayasalc1lık, halk iradesinin tecellisi yoluyla demokratik meşruiyete sahip olabilir. Dolayısıyla demokratik yöntemlerle kabul edilmiş anayasalar, en az yasama organınca çıkarılan kanunlar kadar meşru görülmelidir. Üstüne üstlük, anayasaların olağan yasaları yapan çoğunluklarca değiştirilememesi gayrimeşru görülemez; bu da bizi başa, demokrasinin var oluşundan önceki gereklerine götürecektir. Bununla beraber, illiberal demokrasinin uzak bir tehditten siyasi gerçeklik niteliğine yükselişinin çağında, anayasalcıllğın demokrasiyi ve hakları koruyucu konumu sorgulanmaya açık bir niteliktedir.
\end{abstract}

Anahtar Kelimeler: Anayasalcılık, Demokratik Meşruiyet, Siyasi Eşitlik, Özgürlük, Temsil, Sınırlı Devlet, İlliberal Demokrasi.

Ankara Yıldırım Beyazıt Üniversitesi Hukuk Fakültesi Anayasa Hukuku Anabilim Dalı, karadasabugra@gmail.com, ORCID ID: 0000-0002-3020-9222 (Geliş Tarihi: 03.05.2019 -Kabul Tarihi: 10.10.2019). 


\title{
THE RELATION BETWEEN CONSTITUTIONALISM AND DEMOCRACY: A CEASELESS CONFLICT OR A SYMBIOTIC COEXISTENCE?
}

\begin{abstract}
Democracy, which has its origins from Ancient World, rests on popular sovereignty. On the other hand, constitutionalist theory is interested in limiting and constraining that sovereignty regardless of its source. However it seems inevitable to have a conflict between democracy and constitutionalism given those two concepts' different aims and purposes, there is also a way to mutual existence. This way could be found with the help of the compass of pre-existence needs of democracy which are political equality and freedom. As human experience shows, public masses and their representatives could be inclined to tyranny as much as absolute kings. Furthermore, constitutionalism could have democratic legitimacy through popular will. Thus, democratically enacted constitutions should be regarded no less legitimate than laws passed by legislative bodies. Additionally, not to let constitutions be amended by the same majorities who could enact ordinary laws could not be regarded as illegitimate, which brings us back to the beginning, namely, to the protection of pre-existence needs of democracy. Nevertheless, in the era of illiberal democracy's ascension into political reality from being a distant threat, the status of constitutionalism as a protector of democracy and rights could be questioned.
\end{abstract}

Keywords: Constitutionalism, Democratic Legitimacy, Political Equality, Freedom, Representation, Limited Government, Illiberal Democracy. 


\section{GİRIŞ}

İnsanların topluluklar halinde yaşaması, bu toplulukların en iyi nasıl yönetileceği sorununu beraberinde getirmektedir. Bu hususta pek çok görüş ileri sürülmüş ${ }^{1}$ ve deney yapılmıştır. Günümüze gelindiğinde, ideal idare tarzı olarak demokrasi geniş kabul görmüştür. Her ne kadar geniş kabul görüyor olsa da demokrasi kavramının içeriği üzerinde bir oydaşma sağlanamamaktadır. Gerek düşün bazında gerekse de uygulamada bu konuda derin ayrılıklar ortaya çıkmış$\operatorname{tir}^{2}$.

Demokrasi kavramı üzerindeki fikir ayrllıkları, ülkelerin siyasi ve hukuki yaşamlarına derinden etki etmiş, anayasalcılık kavramı ekseninde derin uygulama ayrılıkları ortaya çımıştır. Bununla beraber, söz konusu ayrılıklar ne kadar derin olursa olsun, demokratik rejimler ortak bir özü paylaşmışlardır. Bu öz, demokrasinin her bireyin görüşünü karar alımında eşit önemde kabul edişine dayanır ${ }^{4}$. Eşitlik anlayışı sayesinde bireylerin karar alım süreçlerine özgürce katılımı bütün demokratik rejimlerde ortak bir unsur olarak gözlemlenmektedir.

Anayasalcılık kavramısa bir idare tarzı olmaktan ziyade, siyasi iktidarın çerçevelendirilmesine yöneliktir ${ }^{5}$. Başka bir deyişle, demokrasi siyasi iktidarın sahibinin kim olduğuyla ilgilenirken; anayasalcılık bu siyasi iktidarın kullanımının sınırlarıyla ilgilenmektedir.

Günümüz düşünce dünyasına şekil vermiş olan pek çok Antik Yunan düşünürü de bu meseleye kafa yormuştur. Çoğunluğu soylu sınıftan gelen ve kitlelerin idarede söz sahibi olmasını sakıncalı gören bu düşünürler, demokrasinin zayıflı̆̆ olarak gördükleri yönlerini acımasızca ortaya koymuşlardır. Bkz. Aristoteles (2017) Politika (Çeviren: Akderin, Furkan), 3. Baskı, İstanbul, Say Yayınları, s. 202-203; Aristoteles'e göre demokrasilerde adalet konusunda yeteneğe değil, sayısal üstünlüğe bakılır. Çoğunluğun adil olduğunu söylediği şey adil sayılır. Aynı şekilde demokrasilerde soylu olmamak, kültürsüzlük ve fakirlik erdem sayılır; Bu konuda ayrıca bkz. Uygun, Oktay (2017) Demokrasi, 3. Bask1, İstanbul, On İki Levha Yayıncılık, s. 91-95.

2 Demokraside yönetme hakkının bütünüyle çoğunluğa ait olduğunu kabul eden Westminster tipi çoğunlukçu demokrasiyle, yönetimin mümkün olan en büyük çoğunluğun uzlaşısıyla gerçekleştirilmesi gerektiğini ileri süren oydaşmacı demokrasiye dair bkz. Lijphart, Arend (Tarihsiz Baskı) Çağdaş Demokrasiler (Çeviren: Özbudun, Ergun/Onulduran, Ersin), Ankara, Yetkin Yayınlar1, s. 13-35.

3 Fransızcası constitutionnalisme, İngilizcesi constitutionalism olan ilgili kavramın, Türkçe'ye daha doğru çevirisinin "anayasacılık" yerine "anayasalcılık" olduğuna ve bu çevirinin ilgili kavramın ruhuna daha uygun olduğuna dair bkz. Özbudun, Ergun (2017) Anayasalc1lık ve Demokrasi, 2. Baskı, İstanbul, İstanbul Bilgi Üniversitesi Yayınları, s. 3. Biz de yazımızda yaygın olarak kullanılan "anayasacılık" kavramı yerine, ilgili terimin daha doğru bir çevirisi olarak görülebilecek "anayasalcılı" kavramını tercih ettik. Zira anayasalcılık ifadesinin kullanımı, yalnızca anayasalı/anayasal devlet kavramlarında da görülebilecek ayrımın constitutionalism ifadesinin ruhuna uygun şekilde ortaya konmasına hizmet etmemektedir. Constitutionalism, yazilı herhangi bir anayasaya bağllı̆̆ı değil, temel hakların korunması amacıyla sınırlı iktidar ilkesine bağluluğu ifade etmekle beraber; constitutional ifadesi, Türkçe'ye ancak "anayasal" olarak çevrilebilir. Sonuç olarak constitutionalism de, anayasalcılık olarak çevrilir. Bu durumda hem yalnızca yazılı herhangi bir anayasaya değil, sınırlı iktidar ülküsüne bağlılığın kavramsallaştırılması açısından; hem de dil bilgisel açıdan daha doğru çeviri, anayasalc1lıktır.

4 Post, Robert (2005) "Democracy and Equality", Law, Culture and the Humanities, C: 1, S: 2, s. 147.

5 Zakaria, Fareed (1997) “The Rise of Illiberal Democracy”, Foreign Affairs, C: 76, S: 6, s. 25-26. 
Tarihsel süreçte anayasalcılığın gelişim çizgisinin başlangıcının tespiti için Ortaçağ, ilgi çekici bir dönemdir. Örneğin, Ortaçağ’da özgür şehirlerce krallardan elde edilen beratlar, kral iktidarının sınırlandığını teyit eden belgelerdi'. O döneme özgü bu tip gelişmeler, günümüz anayasalcılı̆̆ına giden yolda kilometre taşları olarak düşünülebilir?

Ortaçağ anayasalcılığında da, Aydınlanma Çağı düşüncesi ve özellikle liberal felsefeyle beslenmiş modern anayasalcıllkta da temel amaç, siyasal iktidarın kullanımını sınırlamaktır. Ortaçağ'da bu yolla şehirlerin, bölgelerin, seçkin toplumsal sinıfların hukuku korunurken, ${ }^{8}$ modern anayasalcılıkta odak liberal felsefenin de etkisiyle bireyin korunmasına kaymıştır. Böylece günümüz anayasalcılığı; siyasal iktidar karşısında bireyin hukukunun korunmasının amaçlandığı bir düşünce sistemi olarak karşımıza çıkmaktadır 9 .

Öte yandan günümüz anayasalcılığı Aristo'nun politeia ${ }^{10}$ kavramıyla ilişkilendirilse de bu kavram, iktidarın sınırlandırılmasından ziyade düzenlenmesine ilişkindir ${ }^{11}$. Bu bakımdan anayasalcılığın gayesiyle Aristo'nun politeia kavramı bağdaşmaz.

Anayasalcılık ve demokrasinin, sahip oldukları farklı amaç ve içeriklere rağmen, siyasal alana ilişkin olmaları bir teması kaçınılmaz kılmıştır. Bu temas, ilgili kavramların çeşitli anlayış ve yorumlanış biçimleri dolayısıyla kimi zaman çatışmalı kimi zamansa uyumlu bir çizgide seyretmiştir. Her halükarda sağlıklı bir hukuki ve siyasi düzene sahip olmak için anayasalcılık ve demokrasi arasındaki ilişki açıklığa kavuşturulmalıdır. Bu yazının temel problemi de budur.

6 Şehirlerde yaşayan kimselerin toprak sahibi soylulardan aldıkları beratlarla serf olmanın getirdiği sınırlamalardan kurtulduğuna, ticaret serbestisine sahip olduğuna ve kimi şehirlerin aldıkları beratlarla bağımsızlı̆ga yaklaşan yetkiler kazandığına dair bkz. Huberman, Leo (2014), Feodal Toplumdan Yirminci Yüzyıla (Çeviren: Belge, Murat), 15. Baskı İstanbul, İletişim Yayınları, s. 40-44.

7 Levy, Jacob T. "Montesquieu's Constitutional Legacies", Kingston, Rebecca E. (Editör) Montesquieu and His Legacy (2009a), 1. Bask1, State University of New York Press, New York, s. 115

8 Levy, Jacob T. (2009b) "Not so Novus an Ordo Constitutions Without Social Contracts", Political Theory, C: 37, S: 2, s. 200.

9 Friedrich, Carl (2014) Sınırlı Devlet, (Çeviren: Turhan, Mehmet), 2. Baskı, Ankara, Liberte Yayınları, s. 142.

10 Aristo'nun "politeia"sı özel alanı korumak için sınırlandırılmış bir idaredense, dengeli ve iyi bir idareye ilişkindir. Bu konuda bkz. Jobart, Jean-Charles (2006) "La Notion de Constitution chez Aristote" Revue française de droit constitutionnel, C: 65, S: 1, s.121-122; Bu bakımdan politeia kuvvetler ayrımından ziyade dengeli hükumet kavramıyla ilişkilidir. Dengeli hükumet ve kuvvetler ayrılığına ilişkin olarak bkz. Özbudun (2017), s. 13-15.

11 Sartori, Giovanni (1962) “Constitutionalism: A Preliminary Discussion”, The American Science Review, C: 56, S: 4, s. 860. 


\section{DEMOKRASI KAVRAMI VE UYGULAMASI}

Bir ideal olarak demokrasi, halkın kendi kendini yönetimi olarak tanımlanabilir. Bir başka meşhur tanım, ABD Başkanı Abraham Lincoln tarafından "halkın, halk için, halk tarafından yönetimi” olarak yapılmıştır ${ }^{12}$. Bu manasıyla demokraside, idare edenle idare edilenin özdeşliği vardır ${ }^{13}$. Halkın idaresi, başka bir deyişle de iktidarın halk tarafından kullanımı bir ideal olarak kelimelere kolayca dökülebiliyor olsa da uygulamaya aynı şekilde geçememektedir.

\section{A. GEÇMİSTTEN GÜNÜMÜZE DEMOKRASİ PRATİ̈İ: DOĞRUDAN VE TEMSILII DEMOKRASI}

Toplulukların yönetiminde demokratik usullerin geçmişi günümüzden binlerce yıl önceye dayanmaktadır ${ }^{14}$. Antik Yunan dünyasının en etkili şehir devletlerinden birisi olan Atina'da demokratik yönetim hâkimdi. Malum olunduğu üzere demokrasinin kendisi de, Yunanca bir kelimedir. Atina'nın bütün vatandaşları, devletin idaresine katılma ve bunu yönlendirme hakkına sahipti ${ }^{15}$. Buna rağmen vatandaş olmak için erkek olmak, köle olmamak gibi şartlar aranıyordu. ${ }^{16}$ Dolayısıyla demokrasinin temel direği olarak görülen siyasi eşitliğin günümüzdeki kadar dahi mevcut olduğundan söz etmek güç$\mathrm{tü}^{17}$.

Atina'daki vatandaşların devlet idaresine ilişkin sahip oldukları hakları doğrudan kullanması söz konusuydu. Kamusal konularda forumda toplanan vatandaşlarca tartışmalar yapılıyor ve bu konulara ilişkin kararlar ekklesia'da yahut dikasteria'da yapılan oylamalar neticesinde alınıyordu ${ }^{18}$. Nitekim Atina Demokrasisine "doğrudan demokrasi” denmiştir. Buna rağmen Robert Dahl'in de işaret ettiği gibi, kararların alınmasına bütün vatandaşların söz

12 Bu ifadeler, Abraham Lincoln'ün ABD İç Savaşı'nın yönünü tayin eden olaylarından olan Gettysburg Muharebesi'ni takiben verdiği ve Gettysburg Söylevi olarak bilinen nutkunda “...government of the people, by the people, for the people..." olarak yer almaktadır. 272 kelimelik nutkun tam metni için bkz. Lincoln, Abraham, Cornell University Rare and Manuscript Collections, "The Gettysburg Adress", $<$ http://rmc.library.cornell.edu/gettysburg/good_cause/transcript.htm>, s.e.t. 19.03.2019.

13 Kelsen, Hans (2019) Demokrasi: Doğası \& Değeri (Çeviren: Uysal, Yasin), 1. Baskı, Ankara, Dost Kitabevi Yayınları, s. 22

14 Demokrasinin binlerce yıl önce pek çok bölgede ve birden çok defa icat edildiğine dair bkz. Dahl, Robert A. (2017) Demokrasi Üzerine (Çeviren: Betül Kadığlu), 4. Baskı, Ankara, Phoenix Yayınevi, s. 15-17.

15 Anayurt, Ömer (2018) Anayasa Hukuku: Genel Kısım (Temel İlkeler, Kavram ve Kurumlar), 2. Bask1, Ankara, Seçkin, s. 436.

16 Anayurt, s. 437.

17 Siyasi eşitlik, “...erişkinler(in) arasında hiç kimse diğerlerinden, devlet yönetimi bağlamında eksiksiz ve nihai otoriteyle donatılmasını gerektirecek kadar, daha yetenekli...” olmadığı fikrine dayanır. Bkz. Dahl, Robert A. (2018) Siyasi Eşitlik Üzerine, (Çeviren: Zeybekoğlu, A. Emre) 1. Baskı, Ankara, Dost Yayınları, s. 17.

18 Ober, Josiah (1993) "Public Speech and the Power of the People in Democratic Athens", Political Science and Politics, C: 26, S: 3, s. 483-484. 
hakkını kullanarak katılması mümkün değildi ${ }^{19}$. Bilakis bazı önde gelen vatandaşların görüşleri dikkatle dinlenir, diğerlerinin bu görüşleri takip etmesi yahut reddetmesi yoluna gidilirdi ${ }^{20}$.

Demokrasi, yalnızca vatandaşların siyasi eşitliğine dayanmamaktadır. $\mathrm{Bu}$ bakımdan Hans Kelsen, siyasi eşitliğin ötesinde demokrasinin hareket noktası olarak özgürlüğü işaret etmektedir. Kelsen'e göre, demokrasiyi ve bunun pratiğe yönelik bir zaruri sonucu olan çoğunluk idaresini ${ }^{21}$ özgürlüğe dayandırmak salt eşitlik kaynaklı açıklamalardaki mekanik boyutu ortadan kaldırır ${ }^{22}$. Kelsen'e göre, demokraside yurttaşlar verdikleri oylarla itaat eden olmaktan çıkar; fakat bu çıkış yalnızca çoğunlukta olan ve bu çoğunluğun içinde kalanlar için mümkündür ${ }^{23}$. Neticede, mümkün olan en fazla sayıda bireyi özgür kılabilmek için, mutlak çoğunluğa yaklaşan kitlelerle kararlar almak gereklidir ${ }^{24}$.

Temsili yapıysa ulus devletin demokrasi üzerindeki zorunlu bir sonucudur $^{25}$. Zira on altıncı yüzyıldan itibaren Ortaçağ’’n mirası üzerinde yükselen modern ulus devletleri, binlerce kilometrekarelik alanlarda milyonlarca insanı uyruğu haline getirmekteydi. Britanya Adası'nı nihayetinde parlamentonun üstünlüğü ilkesine götürecek olan istisna göz ardı edilirse, bu uluslar evvela mutlak kralların otoritesi altında yaşadı. Öte yandan adem-i merkeziyetçiliğin yok edilip iktidarın merkezileşmesinde kralın yanında duran burjuvazi, artık iktidarın kullanımı tekelini de eline almak niyetine sahipti ${ }^{26}$. Bu noktada iktidarın halk kitlelerince kullanıldığı demokrasi kavramı araçsallaştırıldı ve Antik Yunan'dan sonra uykuya dalan demokrasi düşüncesi Aydınlanma Devri'nde yeniden uyand ${ }^{27}$.

Öte yandan demokrasi de her problemi çözememekteydi. Bilakis iktidarın kullanılması probleminin çözümü, hem sistemin işlerliği hem de burjuvazi çıkarlarının korunması için şarttı. Demokrasi, halkın halk tarafından idaresiyse herkes karar alım sürecine katılmamalı mıydı? Bu noktada Ortaçă̆’ın temsil kurumunun ${ }^{28}$ Antik Çağ’ $ı$ mirası olan demokrasinin içine yerleştirilmesi bir çözüm olarak ortaya çıtı. Böylece ortaya atılan millet egemenliği teorisiyle halk ve millet

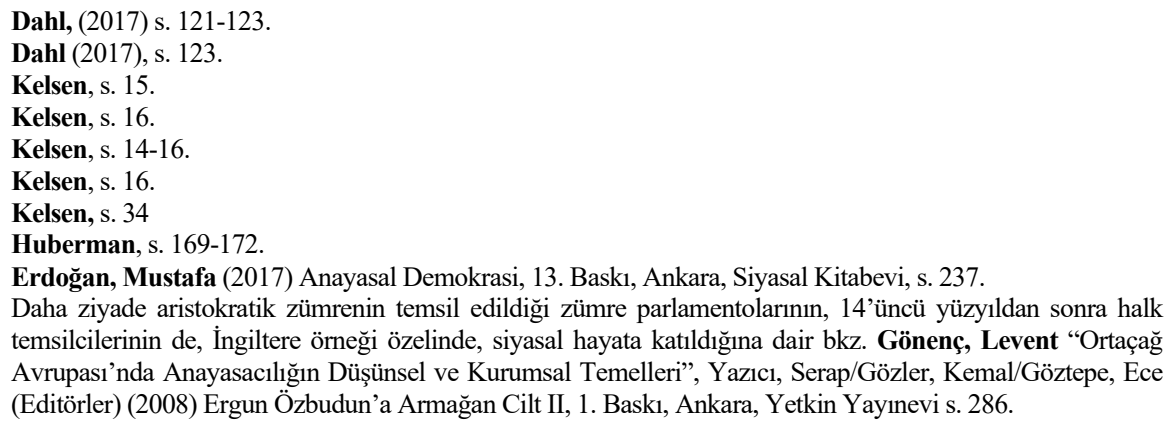
temsilcilerinin de, İngiltere örneği özelinde, siyasal hayata katıldığına dair bkz. Gönenç, Levent "Ortaçağ Avrupası'nda Anayasacılığın Düşünsel ve Kurumsal Temelleri”, Yazıcı, Serap/Gözler, Kemal/Göztepe, Ece (Editörler) (2008) Ergun Özbudun'a Armağan Cilt II, 1. Baskı, Ankara, Yetkin Yayınevi s. 286. 
kavramları arasında bir ayrım yapıldı. Geçmişi, günümüzü ve geleceği hep birlikte kapsayan soyut bir millet kavramı öne sürüldü ve egemenliğin yalnızca günümüzde yaşayan vatandaşlara değil, bunların geçmişte yaşayan atalarına ve gelecekte yaşayacak altsoylarına da ait olduğu savlandi ${ }^{29}$. Bu soyut kavramın yönetme hakkıysa ancak temsilcilerinin vücudunda tecessüm edebilirdi. Kısacası, bu “...'millî egemenlik', bir yandan monarkın egemenliğine son verirken, öte yandan da iktidarın halk yığınlarının eline geçmesini ve doğrudan kullanılmasına engel olacak bir formüldï̈."”

Bu teori, iki sorunun birden çözümüne hizmet etmekteydi. Birincisi, yönetme hakkının tabana yayılmadan belirli bir zümrenin elinde kalması gereğiydi. Temsil teorisi, siyasi haklara bir bütün halinde nüfuz ederek hem seçenlerin hem de seçilenlerin belirlenmesinde yeni iktidar sahiplerine hizmet etti ${ }^{31}$. İkincisiyse, modern ulus devlette demokrasinin o güne kadar bilinen pratiğinin uygulanmasının imkânsızlığıdır. Artık sayısı milyonlarla ölçülen vatandaşlara sahip olan, bir ucundan öbür ucuna seyahat etmenin haftalar hatta belki de aylar süreceği büyüklükteki devletlerin yönetiminde doğrudan demokrasinin ülke çapında uygulanması imkânsızdı. Hâlbuki temsil kurumu sayesinde belirli sayıdaki temsilci bir araya gelip temsil ettikleri millet adına karar alabilirlerdi.

Aydınlanma Çağı'ndan sonra demokrasi, pratikte halkın kendi kendini ancak temsilcileri eliyle yönettiği idare tarzı haline geldi. Devrin önemli düşünürlerinden biri olan Jean-Jacques Rousseau, egemenliğin kullanımının halkı oluşturan her bireyin iradesinin toplamı olan genel iradenin ortaya konulması olduğunu ${ }^{32}$, bu egemenliğin bölünmez ve devredilmez bir nitelik taşıdığını ${ }^{33}$ ve dahası hükümetin bu egemenin ancak bir uzvu olduğunu savlayarak millet egemenliği teorisine karşı çıkar ${ }^{34}$. Buna rağmen Rousseau dahi toprakları geniş ve büyük bir nüfusa sahip Polonya için düşüncelerinde temsil kurumuna yer verdi ve bu kurumun varlığının zaruretinden bahsettiyse $\mathrm{de}^{35}$ temsili vekalet hakkındaki olumsuz görüşleri, bu kurumun Ortaçağ'da ortaya çımış ve aristokratik bir nitelik taşıor oluşundan ötürü baki kaldı ${ }^{36}$.

Teziç, Erdoğan (2017) Anayasa Hukuku (Genel Esaslar), 21. Baskı, İstanbul, Beta, s. 111.

Teziç, s. 111.

Anayurt, s. 453.

Rousseau, Jean-Jacques (2013) Toplum Sözleşmesi (Çeviren: Vedat Günyol), 10. Baskı, İstanbul, Türkiye İş Bankası Kültür Yayınları, s. 55.

Rousseau, s. 23-26.

Rousseau, s. 54-55.

Teziç, s. 115.

Ağaoğulları, Mehmet Ali (2010) Ulus-Devlet ya da Halkın Egemenliği, 2. Baskı, Ankara, İmge Kitabevi

Yayınları, s. 101-102 


\section{B. TEMSILII DEMOKRASİ UYGULAMASININ SONUÇLARI ÜZERIINE DÜŞÜNCELER}

Doğrudan demokrasinin modern ulus devletteki imkânsızlı̆̆ından doğan ve millet egemenliği teorisinin temsil kurumuyla yoğrulan "temsili demokrasi” uygulaması incelemeye değer çeşitli sonuçlar ortaya çıkarmıştır.

Her şeyden önce, temsil ilişkisi aracılı̆̆ıyla iktidarın kaynağı ve kullanıcıları ayrışmıştır. İktidarın sahibi ve yegâne kaynağı olan millet, bu iktidarını çeşitli kurumlar eliyle kullanmak durumunda kalmıştır. Millet adına onun iktidarını kullananlarsa fiili güç sahipleri olarak bir siyasi elit haline gelmişlerdir $^{37}$. Ayrıca yukarıda da bahsettiğimiz gibi, temsil yollu bir siyasi elit yaratma eğilimi doğrudan demokrasilerde dahi gözlemlenebilir.

Demokratik idare usulüne göre topluma ait olan iktidarı kullanan bir zümrenin varlığından çıkarılabilecek sonuçlar nelerdir? Birincisi, bir ideal olarak demokrasiyle uygulama arasında derin ayrılıkların var olduğudur. "Halkın, halk için, halk tarafından yönetimi" olarak idealize edilen demokrasi, fiili düzlemde; halkın, çeşitli gayelere yönelik olarak, halk tarafından seçilenlerce yönetimi şeklini almaktadır. Bu durum, pek çok yazar tarafından ele alınmıştır. Dahl, bu idarelere "poliarşi ${ }^{38 "}$ adını vermektedir ${ }^{39}$. Temsili demokrasinin ideal biçimiyse temsilcilerin halkın eğilimlerine uygun oluşu haline gelmiştir ${ }^{40}$.

İktidarı halk adına kullanan bir zümrenin varlığından çıkarılabilecek bir ikinci sonuç, siyasi iktidarın kullanılmasına getirilen sınırların demokratik ideallerle bütünüyle uzlaşmaz olduğu savının reddedilebileceğidir. Zira uygulanagelen sistem, siyasi iktidarın kullanılmasını belli insan gruplarına terk ederek ideal demokrasiden sapar. Demokrasinin ideal tanımından sapıldığ 1

37 Temsili sistemin düşüncesinin altında yatan görüşün toplumun genel menfaatlerini temsil etmeye mukadder bir kesimin bulunduğuna ve bu kesimlerin 19'uncu yüzyılda aydınlanmış toprak sahipleri, günümüzdeyse profesyonel siyasetçi sınıfi olduğuna ve de temsilin toplumsal sınıflar arasındaki hiyerarşik bir mantığa dayandığına dair görüşler için bkz. Rancière, Jacques (2018) Nasıl Bir Zamanda Yaşıyoruz?, (Çeviren: Erşen, Murat) 1. Baskı, İstanbul, Metis Yayınları, s. 16.; Öte yandan siyasi elit kavramının tanımlanmasında zorluklara dair bkz. Turhan, Mehmet (2000) Siyasal Elitler, 2. Baskı, Ankara, Gündoğan Yayınları, s. 32-40; Bununla beraber siyasal elitin “...siyasal iktidara diğerlerinden daha fazla sahip olan kişiler..." olarak tanımlanabileceğine dair bkz. Turhan, s. 41; Toplumun belli bir kesiminin siyasal iktidara diğerlerinden daha fazla sahip olması olgusu, demokrasinin eşitlik temelli yaklaşımıyla çelişki içindedir.

38 Poliarşi kavramına dair bkz. Dahl (2017), s. 104-107.

39 Günümüzdeki durumsa, Colin Crouch'a göre parabolik bir demokratik gelişimin tepe noktasından sonra demokrasinin gerileme sürecidir. Yazar demokratik idealden uzaklaşılan bu sürece, "post-demokrasi" adını vermektedir. Yazara göre 21'inci yüzyılda yaşadığımız post-demokratik sürecin kendine has bazı özellikleri vardır. Bunlardan bazıları: kamuoyunun, siyasetçiler tarafindan iletişim tekniklerini kullanarak manipüle, siyasal katılımda temsilcilerine teslim olmuş vaziyette pasifize edilmesi; toplumsal müzakere yollarının azalmasından ötürü kişiselleşmiş siyaset ve sıradan insanın karşısında siyasete etki eden bir güç olarak küresel şirketlerin varlığıdır. Bkz. Crouch, Colin (2016) Post- Demokrasi, (Çeviren: Zeybekoğlu, A. Emre), 1. Baskı, Ankara, Dost Kitabevi Yayınları s. 26-36. 
ölçüde, sisteme getirilebilecek sınırlamaların, demokrasinin ve dolayısıyla bir ülkede yaşayan halkın iradesini değil ${ }^{41}$; iş başında bulunan zümreyi kısıtladığ fikrine ulaşılabiliri ${ }^{42}$.

\section{ANAYASALCILIK DÜŞÜNCESI}

Demokrasi, iktidarı kullanılmasına ilişkin paradigmada bir değişim yaratıp iktidarın monarkların elinden alınmasına hizmet etmiştir. Anayasalcılık düşüncesiyse iktidarın kimin elinde olduğundan ziyade, sınırlandırılması gereğiyle ilgilenmiştir. Burada demokrasiye uygunluk bir meşruluk meselesiyken; anayasallık bir hukukilik meselesidir ${ }^{43}$.

Anayasalcllık düşüncesinin hem siyasi hayattaki hem de düşünsel alandaki önemli taraftarlarından James Madison, iktidarın sınırlanması gereğini şöyle ifade etmiştir: "(I)nsanlar melek olsaydı, devlet gereksiz olurdu. İnsanları melekler yönetseydi, devlet üzerinde ne içten ne de diştan bir kontrol gerekir$d i i^{44}$." Halbuki anayasalcılık düşüncesine inananlara göre Lord Acton'ın Mandell Creighton'a yazdığı mektubunda geçen meşhur vecizesi son derece doğrudur: "(G) üç yozlaştırmaya yatkındır ve mutlak güç mutlaka yozlaştırır ${ }^{45}$."

\section{A. ANAYASALCILIK KAVRAMININ TARİHSEL YOLCULUĞU}

Türkçe'ye "anayasa" olarak çevrilen ${ }^{46}$ constitution ifadesi; kurmak, oluşturmak, teşkil etmek manalarına gelen Latince constituere fiilinden türemiş$\operatorname{tir}^{47}$. Öte yandan constitutio ifadesi, 2'nci yüzyıldan itibaren, Roma hukukunda "egemence kabul edilen kararnameyi" ifade etmeye başlad $1 .{ }^{48}$ On dokuzuncu yüzyıla gelindiğinde, bir anayasal sistemden anlaşılan şey, “...birey özgür-

${ }^{41}$ Halkın kendi kendini yönetmek için politika yaratımına, kültürel yahut kurumsal müdahalelerle sınırlamalar getirildiğine dair bkz. Tushnet, Mark (2003) "Forms of Judicial Review As Expressions of Constitutional Patriotism", Law and Philosophy, S: 22, s. 353-354; Yargısal denetimin alanı genişledikçe, tartışmalı ve ancak diyaloğa kapalı bir hukuk yaratımına yol açtığına dair bkz. Tushnet, s. 355-356.

42 Temsilcilerin iradesiyle halk iradesinin doğrudan özdeşleştirilemeyeceğine dair bkz. Anayurt, s. 656-657

43 Tremblay, Luc B. (2011) "Deux thèses sur la démocratie et le constitutionnalisme : la souveraineté du peuple et l'engagement préalable" Revue de droit de l'Université de Sherbrooke, C: 41, S: 3, s. 587.

44 "(I)f men were angels, no government would be necessary. If angels were to govern men, neither external nor internal controls on government would be necessary.” Madison, James 'Federalist No. 51' Carey, George W./McClellan (Editörler) (2001) The Federalist, 2. Bask1, Indiana, Liberty Fund, s. 269.

45 "(P)ower tends to corrupt and absolute power corrupts absolutely.", Lord Acton'dan İngiltere Kilisesi Başpiskoposu olan muhattabına yazılan bu mektubun tam metnine ulaşllabilecek adres için bkz. Dalberg- Acton, Jon, Online Library of Liberty, "Acton-Creighton Correspondance", <https://oll.libertyfund.org/titles/actonacton-creighton-correspondence\#lf1524_label_010> s.e.t. 18.03.2019.

46 "Teşkilât-1 esâsiyye kanunu" teriminin $\bar{d}$ roit constitutionnel ifadesinin daha doğru bir çevirisi olduğuna dair bkz. Gözler, Kemal (1999) Anayasa Hukukunun Metodolojisi 1. Baskı, Bursa, Ekin Kitabevi Yayınları, s. 135; Droit constitutionnel'in konusunun yalnızca yürürlükteki anayasadan ibaret olmadığına dair bkz. Teziç, s. 3 .

47 Merriam-Webster Online Dictionary, $<$ https://www.merriam-webster.com/dictionary/constitute\#etymology> s.e.t. 12.06.2019.

48 Sartori, s. 853 
lüklerinin korunduğu sistem(di)... ${ }^{49}$ " Yeter ki, kural, ilke yahut karşılıklı kurumsal anlaşma yoluyla gücün keyfi kullanımı engellensin ${ }^{50}$. Anayasa ve anayasalcılık kavramları bu şekilde ele alındığı takdirde, temel hak ve özgürlüklerin üstün çeşitli kurallarla korunduğu ve fakat kodifiye edilmiş bir anayasa metnine sahip olmayan Birleşik Krallık'ta da gerçekten bir anayasa olmadığını söylemek güç hale gelir ${ }^{51}$. Yirminci yüzyıldan sonra, olan anayasayla olması gereken anayasa arasında bir ayrım yapılmış olsa $\mathrm{da}^{52}$; anayasalcılık kavramı anlamını korumaya devam etti. Bu kavramın tanımı üstünde kesin bir oydaşma olmasa da, sınırlanmış devlet formülasyonuna genel olarak sadık kalındığı ileri sürülebilirr ${ }^{53}$.

Anayasalcılık düşüncesinin nüvelerine birçok yazarın da işaret ettiği gibi Ortaçağ Avrupası'nda rastlanmaktadır ${ }^{54}$. Burada krala karşı özgür şehirler ve kiliseler kendi hukuklarını savunmak için kralın iktidarının dahi sınırlı olduğu görüşüne sarılmışlardır. Ortaçağ anayasacılığında, bu iktidarın, tanrı buyruğuyla sınırlı olduğu düşüncesi hâkimdi ${ }^{55}$. Tanrı buyruğuna aykırı hareket eden krallar, meşruiyetini kaybeder ve bir tiran olmaktan öteye geçemezlerdi. Bu noktada özellikle kazanılmış haklara saygı ilkesi sayesinde kralın müdahale edemeyeceği özerk bir alanın mevcudiyeti söz konusuydu ${ }^{56}$. Carl Friedrich biraz da bu hususlardan yola çıkarak çağdaş anasayalcılık düşüncesiyle Hıristiyan kültürü arasında bağlantılar bulmaktadır ${ }^{57}$. Biz bu görüşe katılmamaktayız. Birincisi, Hıristiyan kültür dünyasının parçası olmayan pek çok ülkede siyasal iktidarın kısıtlandığı ve bireysel haklara saygılı bir sistemin mevcut olduğu gözlemlenmektedir. Bu ülkelere, Japonya örnek olarak gösterilebilir ${ }^{58}$. İkincisi, Hıristiyan kültür dünyasının bir parçası olmasına rağmen siyasi iradenin neredeyse sınırsızca kullanılabildiği ülkelerin varlığı herkesin

“... a system of protected freedom for the individual...", Sartori, s. 855.

Sartori, s. 855.

Sartori, s. 855.

Anayasanın bir hukuki belge olarak devlet statüsü niteliğinde olduğu, siyasi boyutunun ise 1789 İnsan ve Yurttaş Hakları Beyannamesi'nin 16'ncı maddesindeki insan haklarını teminat altına alma ve kuvvetler ayr1lığını sağlamak olduğuna dair görüşler için bkz. Teziç, s. 161-162; Burada yazılı bir anayasanın varlığı, hukuki niteliği sağlayıp olan anayasayı ortaya koyarken, siyasi boyut bir ideal olarak olması gereken anayasayı teşkil ekmekteydi. Bu görüşün eleştirisi için bkz. Sartori, s. 857-859.

53 Sweet, Alec Stone (2008) "Constitutionalism, Rights, and Judicial Power" Faculty Scholarship Series, Paper: 77 , s. 219; Bununla beraber anayasalc1lığı temel kuruluşa ve pratiğine ilişkin inançlar seti olarak yahut kültürel bir açıdan tanımlayan diğer görüşler için bkz. Sweet, S. 219-220.

54 Bu konuda bkz. Levy (2009a), s. 115; Bu duruma rağmen Ortaçağ anayasalcılığıyla günümüz anayasalcılı̆̆ arasındaki temel bazı farklılıkların da olduğuna dair bkz. Gönenç, s. 270.

55 Gönenç, s. 274.

56 Gözler, Kemal (2009) İdare Hukuku Cilt I, 2. Baskı, Bursa, Ekin Kitabevi, s. 119-120.

57 Friedrich, s. 36.

58 Lijphart, s. 37. 
malumudur. Bunlara örnek olarak da Rusya'yı gösterebiliriz ${ }^{59}$. Dolayısıyla Hıristiyan kültürüyle sınırlı iktidar arasında bir pozitif korelasyonun varlığı öne sürülemez.

Aydınlanma Çağı'nın seküler yapısı, anayasalcılık kavramına da sirayet etmiştir. Çağdaş anayasalcılık, tanrısal hukukla değil, doğal haklarla siyasi iktidarı sınırlama amacı gütmüştür. Doğal haklar teorisi, hakların tanrıdan değil, insan doğasından kaynaklandığı düşüncesi üzerine yükselir ${ }^{60}$. Buradan itibaren anayasalcılıkta doğal haklar, hukuk ötesi bir niteliğe sahip olarak hukukun devlet tarafindan “...yaratılmasinda, yorumlanmasinda ve uygulanmasında... ${ }^{61 "}$ bir geçerlilik şartı haline gelmiştir ${ }^{62}$.

Locke ve Montesquieu anayasalcılığın, diğer bir deyişle siyasal iktidarın sınırlandırılmasının, kuvvetler ayrılığı ile mümkün olduğunu ileri sürmüşlerdir. Bu noktada Locke'un yaptığı kuvvetler ayrılığ squieu'nün yasama-yürütme-yargı kurgusu eksenindeki ayrım geniş çapta kabul görmüştür. Yukarıda da bahsettiğimiz gibi her ne kadar bu yeni anayasalcılık, seküler bir yapıyı haiz olsa da, Ortaçağ anayasalcıllı̆ından doğrudan bir kopuş anlamına gelmeyecektir ${ }^{64}$. Kâdir-i mutlak olmayan bir iktidarın varlığının doğru ve gerekli olduğu yargısının yanı sıra; Kral, lordlar ve avam arasında bir dengeyi öngören İngiliz tipi siyasi örgütlenmenin çağdaş anayasalcılığın önemli kuramcıları olan Montesquieu ve Locke’u etkilemiş olduğu ileri sürülebilirr ${ }^{65}$.

Locke ve Montesquieu'nün kurguladığı kuvvetler ayrilığıyla sınırlandırılmış iktidar, Amerikan kurucuları tarafından işlenmiş ve 1787 ABD Anayasası'nda kabul görmüştür.

59 Rusya'nın otoriter bir yarı-başkanlık rejimi olduğuna dair bkz. Teziç, s. 550.

60 Fukuyama, Francis (2001) "Natural Rights and Human History", The National Interest, S: 64, s. 22.

${ }^{61}$ "(W) hen state officials make, interpret, and enforce law..." Sweet, s. 221.

62 Bununla beraber insan doğasına ilişkin araştırmalar, değerler alanına insan doğasından yapılacak aktarımların tatsız sonuçları olabileceği yönündedir; bu konudaki bir diğer görüş, hakların doğasını insanların doğasında değil, iradesinde arar. Bu görüşün zayıf noktası, hakların yalnızca toplumların iradesine bağlanması sonucunda, kültürel farklılıklar bahanesiyle, söz gelimi, ifade hürriyeti, kişi dokunulmazlığı gibi değerlerin kolayca çiğnenebileceğidir. Bu konuda bkz. Fukuyama s. 23; Demokrasiden önce gelen kimi değerlerin tespit edilememesi yahut aralarında bir derecelendirilme yapılamaması halinde ancak demokratik usullerin sorunların çözümü için bir araç olabileceğine dair görüşler için bkz. Bellamy, Richard/Castiglione, Dario (1997) "Constitutionalism and Democracy - Political Theory and the American Constitution", British Journal of Political Science, C: 27, S: 4, s. 613.

63 John Locke'a göre kuvvetler: yasama, yürütme ve federatif kuvvetti, bu kuvvetler ayrımının daha ziyade toplumsal iradeye ilişkin oluşu ve yasama kavramı etrafında geliştiğine dair bkz. Friedrich, s. 44.

64 Levy, (2008) s. 115-118.

65 Locke için bkz. Friedrich, s. 44; Montesquieu için bkz. Levy, s. 203. 


\section{B. ANAYASALCILIĞIN ARAÇLARI}

Anayasalcılığın gayesini, James Madison şöyle ifade etmiştir: “...ilk olarak hükümetin yönetebilmesini mümkün kilmalısinız, daha sonra da kendi kendini kontrol etmesini sağlamalısınız ${ }^{66}$." Peki, anayasalcılık hangi araçlarıyla siyasi iktidarın kontrollü kullanımını mümkün kılar?

\section{Kuvvetler Ayrılığı}

İktidarın kötüye kullanılmasını önlemek amacıyla sınırlandırılması nasıl olacaktır? Kuvvetler ayrılığı teorisi, iktidarın parçalanarak birbirini dengeleyen ve denetleyen farklı organlara dağıtılması yoluyla bunun mümkün olacağını ileri sürmektedir.

Kuvvetler ayrılığını farklı fonksiyonlara sahip iktidarlara göre tasarla$\operatorname{yan}^{67}$ Montesquieu'ye göre, despotizmin hâkim olmaması için yasama, yürütme ve yargı fonksiyonlarının farklı organlara yahut şahıslara verilmesi ve bunların kati bir şekilde birbirinden ayrılması gerekmekteydi ${ }^{68}$.

ABD Anayasası hazırlanırken, "Kurucu Babalar'ın” önünde; kral, lordlar ve avamın arasında bir dengenin gözetildiği, parlamento içindeki kralın yönetim hakkını haiz ${ }^{69}$ ve henüz yürütme yetkisini eşitler arasında birinci sıfatıyla kullanan bir başbakanın ortaya çıkmamış olduğu Britanya örneği durmaktaydı. Birleşik Krallık’a isyan edilerek kurulan devletin "Kurucu Babalarının” eşitlikçi bakış açısına göre bir kralın varlığı söz konusu olamazdı ${ }^{70}$. Yasama, halkoyuyla seçilmiş Kongre eliyle yürütülebilirse de; yürütme için özgün bir çözüm gerekmekteydi. Zira, "Kurucu Babaları" belki de en çok etkileyen $^{71}$ düşünürlerden olan Montesquieu'ye göre bir makam aynı anda iki

66 "...you must first enable the government to control the governed; and in the next place oblige it to control itself." Madison, "Federalist Paper No. 51", s. 269.

67 Turhan Mehmet (2004) Anayasal Devlet, 3. Baskı, Ankara, Naturel Yayınları, s. 85.

68 Feldman, Jean-Philippe (2010) "La séperation des pouvoirs et le constitutionnalisme. Mythes et réalités d'une doctrine et de ses critiques" Revue française de droit constitutionnel, C: 83, S: 3, s. 483.

Özbudun (2017), s. 13-14.

704 Temmuz 1776 tarihli Bağımsızlık Bildirgesi’nde herkesin eşit yaratıldığı; yaşam, özgürlük ve mutluluğu kovalamanın da arasında bulunduğu Tanrı tarafindan bahşedilmiş, devredilemez haklara sahip olduğunun izahtan vareste gerçekler olduğu ifade edilmiştir; "(W)e hold these truths to be self evident, that all men are created equal, that they are endowed by their Creator with certain unalianable Rights, that among these are Life, Liberty and the pursuit of Happiness.", Metnin orijinal dildeki tamamı için bkz. United States Congress, America's Founding Documents, "Declaration of Independence Transcript", $<$ https://www.archives.gov/founding-docs/declaration-transcript> s.e.t. 24.03.2019.

71 Örneğin kurucu babalardan John Adams'ın Montesquieu'nün öğretisinden derinden etkilendiğine dair bkz. Levy, s. 205. 
kuvveti elinde bulunduramazdi ${ }^{72}$. Henüz önlerinde parlamento içinden çıkan özerk bir yürütme organı örneği de bulunmayan "Kurucu Babalar”, yürütme yetkisini seçilmiş bir krala vermeyi kabul ettiler. Bu seçilmiş kral, Birliğin halkınca belirlenen seçiciler tarafından seçilecek ve belli bir süre için görev yapacaktı. Aynı zamanda federal düzeyde yürütme yetkisini tek başına haiz olacakt1.

"Kurucu Babalar", kuvvetler ayrılı̆̆ını yalnızca çeşitli devlet fonksiyonlarının birbirinden ayrılması olarak ele almamış; denge ve denetimin iyi bir yönetimin en önemli şartı olduğunu düşüncesinden hareket ederek federal bir sistem içinde kuvvetleri dikey şekilde de ayırmışlardır ${ }^{73}$. Böylece merkezi otoriteyi dengeleyen bir de yerel iktidar adacıkları tahkim edilmiştir.

Öte yandan çağdaş siyasal sistemlerde kuvvetler ayrımının klasik anlamı, siyasi partilerin de ortaya çıkışıyla aşınmaya uğrad ${ }^{74}$. Bu durum özellikle yasama ve yürütme ilişkilerinde ortaya çıktı; bir siyasi parti disiplini altında örgütlenen hükümet ve meclis grupları, parti yönetiminin iradesiyle bağlı şekilde hareket etmeye başladi ${ }^{75}$.

Bu noktada, çağdaş siyasal sistemlerde kuvvetler ayrılığının durumuna dair iki görüşten bahsedilebilir. Birincisine göre, kuvvetler ayrılığı artık yargı bağımsızlı̆̆ında somutlaşmaktadır. Yargının bağımsız olduğu bir sistemde, kuvvetler ayrılığının varlığından söz edilebilir. ${ }^{76}$ Bir diğer görüşe göreyse, partiler demokrasisinde kuvvetler ayrılığının yerini bir alternatif olarak muhalefet ve iktidar partileri ayrımı almıştır ${ }^{77}$. Muhalefet ve iktidar arasındaki ayrımdan doğan iktidarı sınırlandırma işlevi, parlamenter rejimlerde ve yarı-başkanlık sistemlerinin kohabitasyon dönemlerinde mümkün olmaktadır ${ }^{78}$. Disiplinsiz ve geçirgen partilerin bulunduğu Amerikan tipi başkanlık sistemlerinde ise partiler arasındaki kuvvet dağılımından daha ziyade başkan, kongre ve yargı arasındaki denge ve denetim yollu etkileşim daha baskındır ${ }^{79}$.

72 Bkz. Montesquieu (2017) Kanunların Ruhu Üzerine (Çeviren: Günen, Berna), 2. Baskı, İstanbul, İş Bankası Kültür Yayınları, s. 199: “(Ş)u üç güç, ayni kişinin veyahut önde gelenlerden veya asillerden veya halktan oluşan aynı kurumun elinde olursa her şey mahvolur..."

73 Dikey kuvvetler ayrılığı, yerinden yönetim ilkesi halinde, federalizm kadar yoğun olmasa da 1982 Anayasasi'nda yer almaktadır.

74 Özbudun, Ergun (2018) Türk Anayasa Hukuku, 18. Basım, Ankara, Yetkin Yayınları, s. 39.

75 Özbudun (2018), s. 39.

76 Özbudun (2018), s. 39.

77 Teziç, s. 496

78 Feldman, s. 491-492.

79 Feldman, s. 492. 


\section{Katı Anayasa ve Anayasa Yarg1sı}

İktidarı tek elde toplamaya yönelik çabalara karşılık olarak kuvvetler ayrılığının yalnızca yöneticilerin iyi niyetine emanet edilmiş bir şekilde var oluşu mümkün müdür? İnsan tecrübesi, otokontrolün ${ }^{80}$ tek başına yeterli bir önlem olmadığının örnekleriyle doludur ${ }^{81}$. Bu sebeple anayasalcı düşünce çareyi bütün devlet organlarını bağlayan, alelade çoğunluklarla değiştirilemeyen ve diğer bütün hukuk kurallarından üstün bir temel yasada bulmuştur.

Bununla beraber yazılı ve katılaştırılmış niteliğe sahip bir anayasası olmayan anayasal rejimlerin mevcudiyetinden de bahsetmek gerekir. Bir anayasal kuralın varlığı için, kodifiye edilmiş olmada olduğu gibi, yazılılığın da ne şart ne de kâfi olduğu söylenebilirr ${ }^{82}$. Yine de, gelenek ağırlıklı olan ve katı olmayan anayasal rejimlerin ancak ve ancak çok özel şartlar altında istisnai olarak ortaya çıktığının kabulü gerekir ${ }^{83}$.

ABD Anayasası'ndan itibaren katı anayasalar, iktidarın sınırlandırılması amacının önemli araçlarından birisi olmuşlardır. Buna rağmen, yalnızca "parşömen bariyer ${ }^{84 "}$ niteliğine sahip anayasalar, iktidarın sınırlandırılmasında yeterli olamamışlardır. Zira zorlayıcı bir dış aktörün yokluğu halinde politikacılar, seçmenlerini tatmin ettikleri takdirde, anayasaya uygunluk meseleleriyle uğraşmamayı seçebilmişlerdir ${ }^{85}$.

Anayasanın uygulanmasını diğer organlara dayatacak üçüncü aktör olan “yargı”, 1803 tarihli klasikleşmiş Marbury v. Madison davasıyla anayasaya uygunluk denetimini yapacak organ olarak ABD'de kendini kabul ettirdi. İlgili kararın gerekçesinde, "(E)ğer mahkemeler Anayasayı dikkate almak zorundaysalar ve eğer Anayasa, yasama organının diğer işlemlerinden üstünse,

80 Çift meclis ve yasama ile yürütme seçimlerinin ayrı ayrı yapılması bu otokontrol araçlarına örnektir, bu konuda bkz. Bellamy/Castiglione, s. 599.

811924 Anayasası döneminde çıkarılan kanunların anayasaya uygunluğunun denetlenememesinin anayasal güvencelere aykırı kanunlar çıkartılmasını kolaylaştırdığı ve özellikle 1954-1960 yılları arasında antidemokratik uygulamaların gözlendiğine dair bkz. Özbudun (2018), s. 31-33; Anayasaya uygunluk denetiminin mevcut olmadığı bir rejimde kanunların anayasaya aykırılığının ancak görünüşte kalacağı, bu durumun hukuki düzlemde karşılık bulamayacağına dair bkz. Gözler, Kemal (2018) Türk Anayasa Hukuku, 2. Bask1, Bursa, Ekin Basım Yayın Dağıtım, s. 81.

82 Alexander, Larry 'Constitutionalism', Christiano, Thomas/Christman, Jon (Editörler) (2009) Contemporary Debates in Political Philosophy, 1. Bask1, Malden, MA, Wiley-Blackwell, s. 287.

83 Örneğin, sivil toplumun son derece örgütlü oluşu ve bu sayede siyaset üzerinde güçlü bir kontrolünün oluşu bu şartlardandır. Bu konuda bkz. Lijphart, s. 21.

84 Madison, James 'Federalist No. 48', Carey, George W./McClellan (Editörler) (2001) The Federalist, 2. Bask1, Indiana, Liberty Fund, s. 256.

85 Seçilmiş makamların, seçmenleri tatmin etmeyecek şekilde anayasayı yorumlaması durumunda makamlarından uzaklaştırılmalarının son derece kolay olduğuna dair bkz. Katyal, Neal K. (2001) "Legislative Constitutional Interpration” Duke Law Journal, C: 50, S: 1, s. 1339. 
anayasanın ve kanunun birlikte uygulanabileceği bir dava, yasama organının bu gibi olağan işlemlerine göre değil, Anayasaya göre karara bağlanmalıdır ${ }^{86}$." denilerek içtihadî yolla anayasallık denetimi kabul ediliyordu. Anayasa yargisı uzun süre boyunca ABD sınırları dışına yayılamasa da, özellikle İkinci Dünya Savaşı'nın sonrasında dünyanın geri kalanına da kendini kabul ettirmeyi başard1 ${ }^{87}$.

Anayasa yargısı organlarının pratiği hak odaklı bir yaklaşımı da tedricen $\operatorname{kapsad}_{1}{ }^{88}$. Bu durum, keyfi iktidarın sınırlandırılmasında kuvvetler ayrılığının korunmasının yanı sıra temel hak ve hürriyetlerin yargı eliyle muhafazası yolunu da açtı. Temel hak ve özgürlüklerin korunmasında uluslararasılaşma, anayasa yargısına da sirayet etmiş; uluslarüstü bir yeni anayasalcılık kavramı da böylece tartışmaya açılmıştır ${ }^{89}$.

Anayasa yargısı da, tıpkı anayasalcılık gibi demokrasi kavramı ekseninde eleştiriye uğramıştır. Demokratik meşruiyete sahip olmayan yargıçlar tarafından demokrasi yoluyla çözülmesi gereken problemlerin sübjektif bir şekilde sonuca bağlanması, kimi zaman meşru görülmemiştir ${ }^{90}$.

\section{ANAYASALCILIK VE DEMOKRASİ İLIŞKİSI}

Toplumların idaresine ilişkin, farklı kaynaklardan ve farklı amaçlarla doğan iki kavramın birbiriyle etkileşime girmemesi kuşkusuz ki mümkün değildir. Bir idare usulü olarak demokrasiyle, idarede keyfiliği engellemeyi amaçlayan anayasalcılığın ilişkisi de farklı görüş ve tartışmalara sebebiyet verdi.

Anayasalcılığın özellikle meşruiyeti bakımından egemenlikle olan ilişkisi ve bir siyasal toplumda gördüğü işlev önem arz edebilmektedir. Öte yandan, anayasal sınırlandırmalardan arındırılmış illiberal demokrasiler, hem

86 Gözler, Kemal (2011) Anayasa Hukukunun Genel Teorisi Cilt II, 1. Bask1, Bursa Ekin Basım Yayın Dağıtım, s. 713; Eserden ilgili kararın gerekçesinin İngilizcesine ve bizim de yazımızda faydalandığımız Türkçe çevirisine ulaşılabilir.

87 Anayasanın normatif üstünlüğünü sağlamanın bir aracı olan anayasallık denetimi, merkezileşmiş bir mahkeme eliyle yahut yaygın denetim yoluyla yapılabilir. Yaygın denetimde yargıcın hukuku uygulama görevinden ve anayasanın da hukukun bir parçası olduğundan hareket edilirken; merkezileşmiş modelde siyaset ve hukukun kesişme alanı olan anayasal problemlerin çözümü için uzmanlaşmış bir mahkeme gereğinin üzerinde durulur; bu konuda bkz. Stone, s. 222-225.

88 Bu gelişim sürecinin kısa bir özeti için bkz. Stone, s.230-234.

89 Bu uluslarasılaşma, kimi yazarlarca neoliberalizmin bütün dünyaya ihracı olarak ele alınmış ve bu eksende eleştirilmiştir, bkz. Türe, Illknur (2016) Yeni Anayasacılık Neoliberalizmin Hukuku, 1. Baskı, Pınar Yayınları, İstanbul, s. 32.

90 Waldron'a göre, bir kurumun demokratik usuller takip edilerek oluşturulmasıyla o kurumun doğasının demokratik oluşu arasında fark vardır. Bkz. Waldron, Jeremy (1999) Law and Disagreement, 1. Baskı, Oxford University Press, New York, s. 257. 
anayasalcılığın etkinliğini sorgulatmakta hem de yokluğunun ne kadar arzulanır olduğuna dair somut ve güncel örnekler olarak ortaya çıkmaktadır.

\section{A. ANAYASALCILIK VE EGEMENLIK}

Millet egemenliği teorisinde egemen olan ve ancak temsilcileri eliyle konuşan millet, kurucu iktidar sıfatıyla bir anayasa oluşturur; böylece millet ve hükümet birbirinden ayrılırlar ${ }^{91}$. Bu anlayışa göre hükümet, milletin temsilcisi sıfatını haizdir ve egemen milletin yaptığı anayasaya uygun hareket etmelidir ${ }^{92}$.

Yukarıda da değindiğimiz gibi, çağdaş demokrasilerin gelişimi ve uygulanmasında millet egemenliği teorisi önemli bir yer tutmaktadır. Ne var ki mevzubahis teori, ne eleştiriden ne de değişimden ari kalmıştır. Rousseau'nun görüşleri çerçevesinde şekillenen halk egemenliği teorisi adı verilen bir diğer teoriye göre, bir ülkedeki egemenlik o ülkedeki bireylerin her birine eşit hisselerle aittir ${ }^{93}$. Bu teori, halktan ayrı bir millet tüzel kişisi yaratıp egemenliği bu soyut millet kavramına terk etmez. Ayrıca yine bu teori sayesindedir ki genel oy gibi günümüz demokrasisinin bazı temel kurumları kabul görmüştür ${ }^{94}$. Günümüzde bu iki teorinin iç içe geçtiği ve aralarındaki sert ayrımların ortadan kalktığı da kabul edilmektedir ${ }^{95}$.

Halk egemenliği teorisinin sonuçlarından birisi, temsilin ancak ulus devletlerin büyüklüğünün ortaya çıkardığı zaruretten ötürü kabulüdür. Bu noktada bir zaruretin dayatması sonucu göreve gelen temsilci, kendisine temsil yetkisini verenlerin iradesiyle bağlı olan bir uzuvdan fazlası değildir ${ }^{96}$.

Buradan çıkacak bir diğer sonuç da, halk egemenliğinin herhangi bir hukuki belgeyle sınırlanamayacağıdır. Egemen olan halk, anayasayı kabul etmek suretiyle bu egemenliğinden vazgeçemez. Bunun yanında, bir neslin temsilcileri kendilerinden sonra gelenleri bağlayacak bir egemenlik yetkisi devrinde de bulunamaz ${ }^{97}$. Bu görüşe göre insanları, önceki nesillerce yapılmış ve demokrasinin ürünü sayılan anayasaları değiştirmekten alıkoymak kendi içinde tutarsızlıklar barındırır ${ }^{98}$. Self determinasyon yoluyla bir anaya-

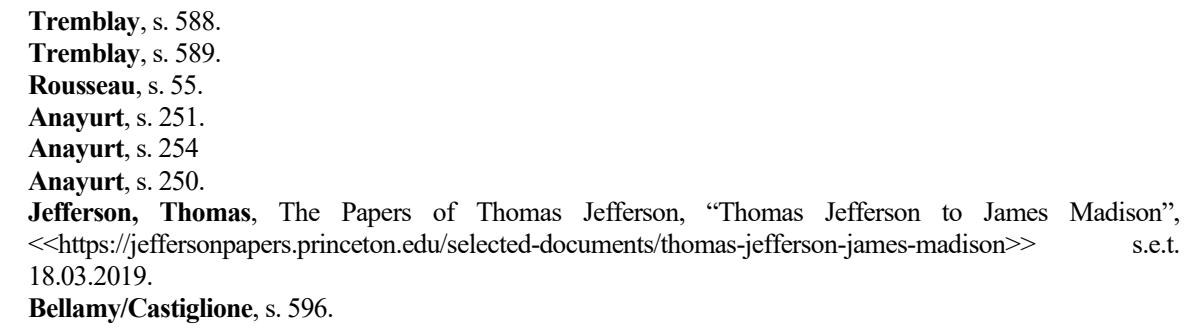


sa yazılmış olması, bunun sonraki nesilleri bağlayarak anti demokratik bir nitelik taşımasına engel olmaz ${ }^{99}$.

Dahası, bir neslin temsilcilerince yapılan hukuki bir düzenleme olan anayasa, sonraki nesillerin temsilcilerinin yer aldığı parlamentoca çıkarılan yasalardan üstün olamaz ${ }^{100}$. Böylesi bir bakış açısı bizi, anayasanın egemenliğinden ziyade parlamentonun egemenliğine götürecektir. Geniş toplumsal kesimlerce uzlaşarak hazırlanan anayasadansa, geçici ve dar çoğunluklar eliyle parlamentoca çıkartılan yasaların evla görülmesiyse, kısa vadeli politik hesapların güdülmesi ve yalnızca grup çıkarlarının ilerletilmesi gibi açılardan sorunludur ${ }^{101}$. Parlamento çoğunluğunun sınırsız egemenliğinin olduğu bir düzende yönetme hakkı halkın çoğunluğuna bütünüyle verilir ${ }^{102}$. Bu yolla siyasi elitlerin sınırsız bir güce kavuşmasının dışında, toplumda azınlığı teşkil eden kesimlerin iktidardan asla pay alamaması bunların rejime olan bağlilıklarını da etkileyecektir ${ }^{103}$.

Her şeyden öte kâdir-i mutlak kabul edilen egemen bir halk varsa, bu halkın bir anayasa kabul edebileceğini kabul etmek gerekir. Zira ya halk egemen sıfatıyla bir anayasa kabul edebilir ya da egemen değildir ${ }^{104}$. Burada halkın egemenliğinin iki karakterli olduğu; hem anayasal meselelerin çözümünde kurucu iktidarı şekillendirdiği hem de seçmen sıfatıyla parlamentoyu seçtiği de ileri sürülebilir ${ }^{105}$.

Bir anayasanın egemen tarafından koyulabileceği kabul edildiği takdirde de, bu anayasanın belli aralıklarla yenilenmesi ancak bir yerindelik problemi olacaktır ${ }^{106}$. Bu noktada da Jefferson'ın hesaplamış olduğu gibi, her on dokuz yılda bir anayasaların geçerliliğinin ortadan kalkması yerine; anayasada değişiklik kanallarını açık tutarak toplumsal dinamiklere göre anayasayı esnetmek daha doğru bir çözüm olacaktır ${ }^{107}$.

99 Waldron, Jeremy (2012) “Constitutionalism: A Skeptical View”, NYU School of Law, Public Law Research Paper No: 10-87, s. 30.

100 Tremblay, s. 590.

101 Dahl (2017), s. 86.

102 Lijphart, s. 13.

103 Lijphart, s. 26.

104 Egemenliğin mutlak ve sinırsız olduğuna dair bkz. Anayurt, s. 241.

105 Tremblay, s. 592

106 Thomas Jefferson'ın anayasaların geçerliliğinin 19 yılda bir yenilenmesi gerektiğini düşündüğüne dair bkz. Gosseries, Axel P. (2008) "Constitutions and Future Generations” The Good Society, C. 17, S. 2, s. 32; Jefferson, doğum ve ölüm oranlarını dikkate alarak yaptığı hesaplamayla o devre göre 19 yılda erginlerin çoğunluğunun değişeceğini ve bunların yeniden anayasayı ele almalarının gerekeceğini ileri sürmüştür. Bkz. Jefferson, dn. 94; Bu görüş, hem nesillerin birbiriyle iç içe geçtiği için ayırt edilemeyeceği hem de nesilleri aşan kimi değerlerin korunması gereğinin daha üstün olduğu gerekçesiyle eleştirilmiştir bkz. Gosseries, s. 33. Değişmez kılınan kuralların pratik yollardan aşılmaya mahkum olduğuna dair bkz. Özbudun (2017), s. 37 
Öte yandan, egemen sıfatına sahip olan toplumun anayasasından vazgeçmeye ve yeni anayasal düzenlemeler vazetmeye kâdir olduğunun da kabulü gerek$\operatorname{lidir}^{108}$. Bu noktada, sinırlı iktidara sahip anayasal bir yönetimin egemen tarafindan tercih edilmesinin, yöneticilerin iradesiyle toplumun iradesinin uyuşması açısından çok daha yerinde olacağını ifade etmeliyiz.

Anayasalcılığın egemenlik ekseninde demokrasiyle bağdaştırılması, sivil topluma duyarlı bir sistemle mümkündür. Bu noktada katılımcı ve özgür bir siyaset ortamı, egemen sıfatını haiz olan toplumun önceden kabul ettiği anayasayı değiştirme iradesine sahip olduğunu tespit etmenin en önemli yolu haline gelmektedir $^{109}$. Bu yolla anayasalcılık, çağdaş ulus devletin zorunlu bir sonucu olan temsili demokrasi organlarını, müvekkillerine kulak vermeye itecektir.

Zira ifade etmek gerekir ki, hiçbir halk kendi anayasasını kendisi yazmamıştır. En demokratik anayasalar dahi temsilciler tarafından hazırlanmıştır. Daha sonra bu metin halkın onayına ya sunulmuştur ya da sunulmamıştı1 ${ }^{110}$. Dahası, yukarıda da değindiğimiz gibi milyonların yaşadığı bir ulus devlette iktidarı millet değil, onun temsilcileri kullanmaktadır. Anayasa, birey hak ve özgürlüklerini korurken büyük oranda bu temsilcilerin kullandığı iktidarı kısıtlar ${ }^{111}$. İster yazılı tek bir metinde olsun isterse de Birleşik Krallık'taki gibi kodifiye edilmemiş olsun; anayasal kurallar, halka her seçimden sonra bir kez daha demokratik usullerle temsilcilerini seçme imkânını verir. Netice olarak demokratik eğilimlere duyarlı bir anayasal düzen, egemenliğin halk tarafından kullanılması gerektiği yönündeki demokratik ideale ihanet etmez; temsili demokrasinin zıt yöndeki eğilimlerini törpüler.

\section{B. FARKLI TOPLUMSAL KESIMLERIN UZLAŞI BELGESİ OLA- RAK ANAYASA VE ANAYASALCILIK}

Anayasalar, farklı toplumsal kesimlerin siyaset alanı üzerinde vardığ 1 uzlaşının bir belgesi olarak da ele alınabilirr ${ }^{12}$. Bu uzlaşıyı da, ilgili kesimler

108 Bu durumda toplumda bir müzakere gereği doğacağına dair bkz. Tremblay, s. 601.

109 Tremblay, s. 596; Tremblay’e göre bu iradenin birçok ifade edilme yolu vardır. Örneğin baskın bir kamusal eğilim, insanların anayasal düzenden memnuniyetsizliğini toplantı ve gösteri yürüyüşü yoluyla ifade etmesi yahut bir kurucu meclis kurulması halkın yeni bir anayasa istediğini gösterir.

110 Demokratik anayasa yapımında; halk tarafından seçilen adil bir dağılıma göre belirlenmiş temsilcilerin varlığı ve açık bir tartışma ortamı, halkoyuna sunulmaktan daha önemli görülebilmektedir. Bu konuda bkz. Teziç, s. 184.

111 Dolayısıyla siyasi elitlerce kullanılan iktidarın kısıtlanması, yalnızca temel hak ve özgürlüklerin tartışmaya kapatılması şeklinde ele alınamaz. İlgili görüş için bkz. Bellamy/Castiglione, s. 600.

112 Bu uzlaşı sürecinin bir anlatımı için bkz. Alexander (2009), s. 283-284. 
adına bunların temsilcileri pazarlık yoluyla gerçekleştirirler ${ }^{113}$. Keyfiliğin önlenmesi amacıyla iktidarın sınırlandırıldığı anayasalcılık felsefesiyle hazırlanan bu belgeler, siyaset alanının sınırlarını çizerek farklı toplumsal kesimlerin birbirine karşı kullanabileceği iktidarı kısıtlayarak ${ }^{114}$ heterojen toplumları oluşturanların bir arada var oluşunu mümkün kılar. Buradaki belge, klasik sosyal sözleşme teorisinde olduğu gibi doğal haldeki bireylerin bir araya gelip sıfırdan bir sosyal yapı kurgulamasının bir aracı olmaktan daha çok, hâlihazırda varlığ 1 devam etmekte olan ve birbirinden farklılık arz eden kurum ve kuralları olan toplulukların, yeni bir siyasi düzen yaratmak için uzlaşmasının aracıdır ${ }^{115}$.

$\mathrm{Bu}$ bağlamda anayasalar toplumların bir arada yaşama vaadi ve isteğinin biçimlendiği metinlerdir ${ }^{116}$. Bu çoğul toplum, genelini ilgilendiren kararların alındığı siyaset alanını anayasa ile tanzim eder. Birbirinden son derece farklı özellikler taşıyan bireylerin özerk alanına yapılacak kamusal müdahalelerin önüne böylece geçilmeye çalışılır ${ }^{117}$. Bu noktada, kamusal olanla özel olanın ayrımının da ancak siyasetle belirlenebileceği argümanıyla anayasalcılık eleştirilmektedir ${ }^{118}$. Bu eleştiri haklılık payı taşımakla beraber, çoğulcu toplumdaki azınlıkların yalnızca siyaset ve bilindik çoğunlukçu demokrasi yöntemleri yoluyla kendilerini koruyamayacakları açıktır. Bu durumda çıkarlar çatıştığı takdirde, sayıca çoğunlukta bulunanın diktatörlüğü söz konusu olabilecektir. Demokratik yöntemlerle anti demokratik kararlar alınabilecektir ${ }^{119}$. Netice olarak anayasaların yalnızca basit çoğunluklarla değiştirilememesi bunları anti demokratik yapmaz.

Hakeza, anayasal korumaların mevcudiyeti, siyasi alanla özel alan arasindaki sinırın siyaset yoluyla belirlenmesini de tamamen engellememektedir. Elbette, siyasetin de, toplumsal görüşlerin özgürce ifade edildiği bir forum niteliğinde olduğu takdirde, yargıya karşı çeşitli avantajları söz konusu olabilir ${ }^{120}$. Örneğin ABD'de New Deal döneminde, o devre kadar yargı organlarının sahip olduğu kimi ön kabuller tedricen ortadan kalkmıştır. Bu

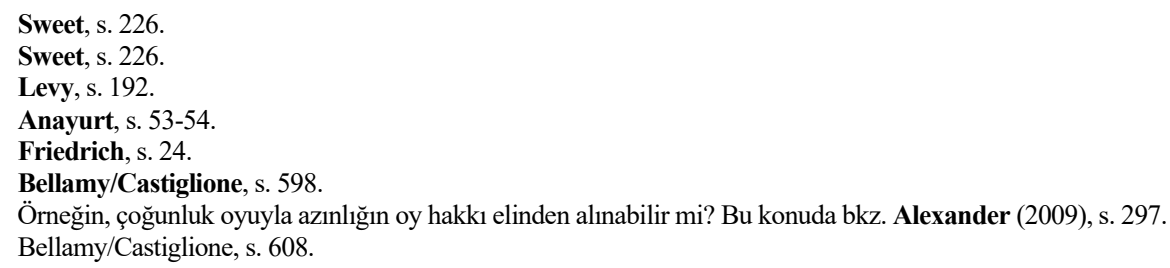


süreçte ortaya çıkan "anayasal engeller ${ }^{121}$ " toplumsal uzlaşıyla aşılabilmiştir ${ }^{122}$. Hulasa siyaset, yargının önüne geçerek özel alanla kamusal alanın s1nırlarını yine çizmiştir. Yalnızca gereken dar bir çoğunluk değil; toplumda geniş çaplı bir uzlaşı olmuştur ${ }^{123}$. Anayasalcılığın çoğulcu toplumda bir arada yaşamı tahkim etme işlevi de ancak böyle ortaya çıkabilmektedir. Dolayısıyla anayasa yargısının o gün için yaşadığı bu yenilgi, anayasalcılık için bir zafer olmuştur.

Demokrasinin pratik sonuçlarından birisi olan çoğunluk ilkesine gö$\mathrm{re}^{124}$, demokrasilerde bir konuda karar alınırken çoğunlukta kalan tarafın dediği olur. Demokrasi, çoğunluğun mutlak hâkimiyeti olarak yorumlandığında anayasalcılıkla derin problemlerin doğması doğaldır. Yine de, yukarıda da bahsettiğimiz şekilde siyasi eşitlik ve özgürlük varsayımına dayanan demokrasilerde, bu eşitliği ve özgürlüğü yok edici kararların çoğunluk tarafından alınarak demokrasinin aşındırılmasını önleyici önlemler öngörülmesi son derece mantıkidir ${ }^{125}$.

Dolayısıyla mevzubahis çoğunluğu anayasal kısıtlamalardan ari biçimde kâdir-i mutlak kılma eğilimi, hem çoğunluğun despotizmine ${ }^{126}$ yol açma ihtimalinden hem de anayasaların da demokratik çoğunluklar eliyle değişebiliyor olduğu gerçeğinden ötürü temelsiz kalmaktadır. Netice olarak politikanın önünü geniş ölçülerde tıkamayan bir anayasal düzen, demokrasi sürecinin daima mümkün kılmaktan öte bir işlev görmeyecektir.

Öte yandan toplumun farklı kesimleri arasındaki birlikte yaşama sözleşmesi niteliğini taşıyan anayasa, bu kesimlerce uzlaşmalarının o an için mümkün olmadığı hususlara ilişkin soyut ifadeler barındırabilirr ${ }^{127}$. Bu gibi soyut ifadelerin anlamlandırılması için anayasal hakem sıfatını haiz olan

121 Anayasalcılığın ikincillik ilkesi (principe de subsidiarité) gereği, özel alanın kamusal alandan önce gelmesi gerektiğine dair bkz. Feldman, s. 496; Kuşkusuz ki bu ilkenin sonuçlarından biri de, kamusal alanla özel alan arasındaki gri bölgede kalan durumlarda özel alanın tercih edilmesi gereğidir.

122 New Deal anayasalcılığı, common law ön kabullerinden yapılan sapmaları doğal nizamdan ayrılış gören yargı pratiğini tedricen aşmıştır. Burada Supreme Court'un siyasi süreçten etkilenerek görüşlerini değiştirmiş olduğuna dair bkz. Sunstein, Cass Robert "Constitutionalism after the New Deal”, Harvard Law Review, C: 101, S: 2, s. 501-502.

123 New Deal reformlarının mimarı Franklin Delano Roosevelt, ABD tarihinin 4 dönem hizmet etmiş tek başkanıdır. Demokratik seçimlerde ABD halkı tarafindan gösterilen geniş tabanlı bu teveccüh, New Deal reformları yönündeki toplumsal eğilimin göstergesi olmuştur.

124 Oybirliğinin pratik imkansızlığı karşısında çoğunluk kuralının demokraside kabul gördüğ̈̈ne dair bkz. Dahl (2017), s. 65-66.

125 Dahl (2018), s. 25-26.

126 De Tocqueville, Alexis (2016) Amerika'da Demokrasi, (Çeviren: Sertdemir Özdemir, Seçkin), 1. Baskı, İstanbul, İletişim Yayınları, s. 260.

127 Stone, s. 226. 
anayasa yargısı organları da yine anayasa koyucuları tarafindan öngörülebilir. Bu noktada seçilme kaygısı güden ve siyasi bir ajandaya sahip olan politikacılardansa, halkın kendisi tarafından yahut temsilcilerince ilgili yetkilerle donatılan ${ }^{128}$ bu organlara anayasal problemlerin çözümünde yetki vermenin kategorik olarak demokrasi dışı olduğunu ileri sürmek güçtür ${ }^{129}$. Yine de, hassas olduğu düşünülen bazı konuların, soyut ifadelerle yargısal çözüm yoluna itilmesi, meselelerin çözümünü geciktirebileceği için statükoyu koruyucu bir etkiye sahip olabilecektir ${ }^{130}$. Dolayısıyla bu tip soyut kuralların yoğun şekilde varlığı ve yargı organlarınca etkin şekilde kullanımı, günlük siyasetin faaliyet alanını fazlasıyla daraltıp anayasanın meşruiyetini aşındırıcı niteliğe kavuşabiliri ${ }^{131}$.

Demokratik meşruiyet sorununun ortaya çıkışı, anayasal meselelerin çözümünde demokratik kanalların tamamen kapalı tutulmasıyla da mümkün olabilir. Söz gelimi, geniş kapsamlı değişiklik yasaklar1 ${ }^{132}$ bu minvalde ele alınabilir.

Anayasanın toplum nazarında meşruiyet krizine girmesi halinde demokratik mekanizmaları çalıştırarak bu talebin karşılanması gerekecektir. Bir kuralın meşruiyet krizi, etkili bir uyuşmazlık çözümü aracı olmaktan çıkmasıyla ortaya çıkar. ${ }^{133} \mathrm{Bu}$ durumda toplum, demokratik usullerle yeni bir anayasal kurallar seti oluşturabileceği gibi; bu yeni kural seti, anayasanın metni değiştirilmeden toplum tarafından anayasaya yüklenen anlamın değişmesi yoluyla dahi olabilir ${ }^{134}$. Zira yukarıda bahsettiğimiz New Deal döneminde olduğu gibi, anayasal yargıçların iradesinin demokratik çoğunluklar tarafından aşılabildiği de bir gerçektir.

Çoğunluğun desteğine sahip olduğunu ileri süren kontrolsüz bir siyasi elit zümrenin ${ }^{135}$ ortaya çıkarak insanlık tecrübesinde çok daha fazla yer kaplayan "tatsız" anılara yol açtığı kuşkusuzdur. Kuşkusuz böylesi bir ortamda

128 Alexander, Larry (2011) "What are Constitutions, and What Should (and Can) They Do?", Social Philosophy and Policy, C: 28, S: 1, s. 20.

129 Sweet, s. 225.

130 Bellamy/Castiglione, s. 601.

131 Özbudun (2018), s. 182, "(T)ecrübeler, anayasa yargısı ile toplumun çoğunluğunu temsil eden siyasal güçler arasında derin ve sürekli görüş ayriliklarının belirmesi halinde, sonuçta anayasanın değiştirilmesi ve anayasa yargısının yetkilerinin kisılması tehlikesinin söz konusu olabileceğini göstermektedir."

132 Değişiklik yasaklarıyla bir asli kurucu iktidarın diğerini kısıtlamasının demokratik usuller yerine şiddet yolunu açacağına dair bkz. Teziç, s. 206.

133 Alexander (2009), s. 289.

134 Alexander (2011), s. 22-23.

135 İktidarın belli ellerde yoğunlaşmasının, özgürlük ve mutluluğa anarşi durumundan dahi daha çok zarar verme potansiyelinin tarihsel olarak Nazi Almanyası, Maoist Çin ve Sovyet Rusyası örnekleriyle gözler önüne serildiği yönünde bkz. Zakaria, s. 32. 
da, ne siyasi eşitliğin ne de özgürlük ve birey özerkliğinin ${ }^{136}$ korunacağ 1 söylenebilir. Bir uzlaşı belgesi olarak katı anayasa, kısa vadeli siyasi çıkarlar uğruna oy hakkı, ifade hürriyeti gibi demokrasi için vazgeçilmez sayılan hususları koruma işlevini görebilecektir ${ }^{137}$.

Bu noktada “...bir ulusun politik hayatındaki büyük bir geçişin sem-

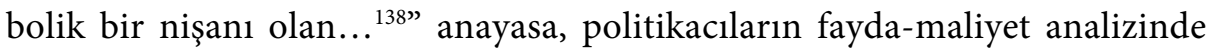
göze alınması zor bir maliyet olarak karşısına dikilmektedir ${ }^{139}$. Elbette anayasadan vazgeçmenin maliyetli olması için, toplumun bu anayasaya bir değer atfetmesi gereklidir.

Anayasallık ve demokrasi arasındaki ilişki, satranç teşbihi ile Tremblay tarafından son derece ilginç bir şekilde anlatılmıştır: "(S)atrancın kurallarının, örneğin, kale, fil, piyonlar veya atların nasıl hareket etmesi gerektiğine dair kuralların; kalenin çapraz, filin düz, piyonların her yönde, atların beş kare atlayarak hareket etme özgürlüğünü kısıtladığını düşünmek haksızlık olurdu. Bu kurallar; kalenin, filin yahut piyonların egemenliğini kısıtlamaz. Satrancı kısitlamazlar; bizatihi satrancin kendisidirler ${ }^{140}$."

\section{C. ÍLLİBERAL DEMOKRASİ VE ANAYASALCILIK}

İktidarın anayasal kurallarca sınırlandığı, hatta bu anayasal kuralların anayasa yargısı organları tarafından dikkatle korunmasının öngörüldüğü sistemlerde dahi siyasi iktidar kontrolden çıabilmekte; otoriteleşme eğilimleri gösterebilmektedir. Anayasa yargısı organlarının son derece güçlü olduğu Polonya ve Macaristan gibi ülkelerde illiberal demokrasi ${ }^{141}$ kavramı çerçevesinde yeni bir tür 21'inci yüzyıl otoriterliği şekillenmektedir ${ }^{142}$.

136 Zakaria, s.30.

137 Alexander (2009), s. 292.

138 “... a symbolic marker of a great transition in the political life of a nation.” Ackerman, Bruce (1997) 'The Rise of World Constitutionalism', Virginia Law Review, Faculty Scholarship Series Paper No: 129, s. 778.

139 Ackerman, s. 779.

140 “(O)n aurait tort de pense que ses règles du jeu d'échec, par exemple, qui déterminent comment la tour, le fou, les pions ou les cavaliers doivent agir, $<<$ limitent $>>$ la liberté de la tour d'avancer en diagonale, celle du fou de se déplacer verticalement, celles de pions d'aller dans tous les sens ou de cavaliers de sauter cinq cases à la fois. Ces règles ne limitent pas la $<<$ souveraineté $>>$ de la tour, du fou ou des pions. Elles ne limitent pas le jeu d'échec: elles $<<$ sont $>>$ le jeu d'échec." Tremblay, s. 602.

141 İlliberal demokrasinin; medeni ve siyasi hakların korunmadığı, temsili organların seçimlerinin çoğu kez özgür ve adil bir ortamda yapılmadığı bir siyasi düzeni ifade ettiğine ve liberal demokrasi yönünde olgunlaşmaktan ziyade illiberal niteliklerinin yoğunlaştı̆̆ına dair bkz. Zakaria, s. 23-24.

142 Bu ülkeler 1990'larda liberal demokrasiye yönelen ülkeler olarak örnek gösterilmiştir bkz. Zakaria, s. 33-34; Anayasa mahkemeleri de son derece güçlü olarak görülmekteydi bkz. Stone, s. 235; Bugün ise hem Polonya hem de Macaristan, illiberal demokrasinin Orta Avrupa'daki kaleleri olarak görülmektedir, bu konuda bkz. Mink, Georges (2016) “L'Europe centrale à l'épreuve de l'autoritarisme", Politique étrangère, S: 2, s. 93; Bu noktada Macaristan'da Anayasa Mahkemesi’nin, üye kompozisyonu Viktor Orban tarafindan değiştirilerek 
1990'larda teorize edilen illiberal demokrasinin bugün bütün dünyada yükselen bir eğilim ve olumsuz bir örnek olarak görülmesi, anayasal güvencelerden yoksun bir demokrasinin ne ölçüde demokratik niteliğini koruyabileceğinin en önemli göstergesidir. Zira bu “demokrasilerin” en yaygın özelliklerinden birisi, siyasi iktidar üzerinde hiçbir kurumsal sınırlamanın olmayışıdir ${ }^{143}$.

Öte yandan dikkatlice düzenlenmiş anayasal kuralların ve anayasa yargısının varlığına rağmen ortaya çıkan illiberal eğilimler, anayasal güvencelerin de siyasal toplum üzerindeki etkisinin büyüklügüne dair soru işaretlerini ortaya çıkarmaktadır ${ }^{144}$. Demokrasinin ve onu çerçeveleyen anayasal kuralların yalnızca birbirini dengeleyen devlet organlarına bırakılması değil, topluma ve bireylere "emanet ve tevdi olunmasi ${ }^{145 "}$ asıl güvenceyi teşkil edecektir.

\section{SONUÇ}

Bir ideal olarak demokrasi, halkın halk tarafından yönetimi; yöneticiyle yönetilenin birleştiği idare tarzı olarak görülebilirse de uygulamada gerçeklikle ideal arasında farklılıklar ortaya çıkabilmektedir. Bu durum, demokrasinin ilk örneklerinden biri olarak görülen Atina Demokrasisinde dahi gözlemlenebilir. Gerek seçmen sıfatının çok az insanın sahip olabildiği bir ayrıcalık, gerekse de Atina'da dahi sözü geçen bazı politikacıların kendilerini temsilci benzeri bir konuma getirecek şekilde kamuoyunu yönlendirebiliyor oluşu demokrasi uygulamasının ilk andan itibaren idealden saptığını göstermektedir.

Günümüz demokrasisiyse, ulus devletler çağının da bir gereği olarak, temsil kurumuyla yoğrulmuştur. Temsil, hem pratik hayatın, hem de demokrasiyi ideal bir yönetim tarzı olarak gündeme getiren burjuva çıkarlarının gereği olarak kabul edildi. Böylece iktidarı mutlak kralların elinden alan

pasifize edildiğine dair bkz. Mink, s. 94-95; Polonya'da ise Anayasa Mahkemesi ve hükümet arasında gergin bir ilişki olduğuna dair bkz. Mink, s. 96.

Anayasal güvencelerin, otoriterliğe giden yolda ancak yavaşlatıcı bir etkiye sahip olabileceğine ve yargısal gücün otoriterleşme arttıkça eriyeceğine dair bkz. Ginsburg, Tom/Huq Aziz Z./Versteeg Mila (2018) "The Coming Demise of Liberal Constitutionalism?", The University of Chicago Law Review, C: 85, S: 2, s. 252253. 
burjuvazi, bunu halk yığınlarıyla paylaşmaktan da kurtuldu. Bu noktada ortaya atılan millet egemenliği teorisi de temsil kurumunu güçlendirdi. Bu teoriye göre egemen sıfatını haiz olan millet, bugün ülke sınırları içinde yaşayan halkı kapsadığı gibi, geçmişte yaşamış ve gelecekte yaşayacak olanları da içine alır. Bu bakımdan millet, halkın bütününden ayrı bir soyut varlıktır. $\mathrm{Bu}$ soyut varlığın iradesiniyse seçimler yoluyla belirlenen temsilciler ortaya koyar. Bu teori, egemenliği ülkede yaşayan insanların ortak hisselerinin toplamı olarak gören halk egemenliği teorisince eleştirilmiştir. Halk egemenliği teorisi sayesinde genel oy gibi günümüz demokrasisinde vazgeçilmez görülen bazı kurumlar uygulamaya geçmiştir. Öte yandan, halk egemenliği teorisinin "fikir babası" sayılabilecek Jean-Jacques Rousseau dahi yazılarında bir ehven-i şer olarak vekâlet kurumuna yer vermiştir.

Anayasalcılıksa, demokrasiden bağımsız olarak gelişmiştir. Demokrasi, iktidarın kullanıcılarıyla ilgilenirken anayasalcılık, kullanılacak iktidarın sınırlarını takdir etmekle ilgilidir. Tarihsel köken bağlamında anayasalcılık ve Aristo'nun politeia'sı arasında amaçsal bir bağlantı kurmak mümkün gözükmemektedir. Buna mukabil, Ortaçağ'daki özgür şehir beratlarının siyasi iktidarı kısıtlayıcı boyutu sebebiyle bir Ortaçağ anayasalcılığından bahsedilebileceği kabul edilmektedir. Dahası kralın, tanrısal bir niteliği haiz olsa da, hukukla bağlı olduğunun kabulü, modern anayasalcı düşünceye giden yolda döşenen bir taş olarak ele alınabilir.

Modern anayasalcılıksa, egemenin hukukunun kısıtlanmasında tanrısal buyruğa değil, seküler bir doğal hukuk yaklaşımına başvurmuştur. Aydınlanma Çağı'nın filozoflarından John Locke ve Montesquieu, hakların korunmasının yöntemi olarak kuvvetler ayrılığını işaret etmektedir. John Locke'un yasama-yürütme-federatif kuvvetler ayrımı yerine kabul edilen Montesquieu'nün yasama-yürütme-yargı ayrımı, mevzubahis farklı fonksiyonların farklı kişi ve organların eline verilmesi gerektiğine, böylece tiranlığın önlenebileceğine yöneliktir. Montesquieu'nün kuvvetler ayrılığı teorisi, Amerikan kurucularını etkilemiş ve Amerikan tipi başkanlık sistemiyle uygulamaya geçirilmiştir.

Çağdaş anayasalcılığın kuvvetler ayrılı̆̆ıyla katı anayasalara ve anayasallık denetimine dayandığı ileri sürülebilir. Her ne kadar yazılı ve katı anayasaların sınırlı iktidarın doğrudan bir varlık şartı olduğunu ileri sürmek güç 
olsa da, bunlardan mahrum bir anayasal sistemin istisnai şartları altında ortaya çıkabileceğinin kabulü gereklidir. Bu noktada anayasallık denetiminde tedricen benimsenen hak ve özgürlükleri koruma işlevi de anayasalcılık için yeni bir boyut oluşturmuştur. Nihayet temel hak ve özgürlüklerin korunmasının giderek daha fazla uluslararasılaşması, anayasalcılık açısından da çeşitli tartışmalara yol açmıştır.

Biri iktidarın kullanımı, ötekisiyse sınırlandırılmasıyla ilgilenen demokrasi ve anayasalcılık arasındaki ilişkiyse kimi zaman bir çatışma olarak gözükmüştür. İki kavram arasındaki ilişkinin çatışma olarak ele anılabilmesi için, mutlak egemen olarak kabul edilen halkın ve onun temsilcilerinin daha önceki nesillerin getirdiği kurallarla gayrimeşru olarak sınırlandığg fikrinin kabulü gerekmektedir.

$\mathrm{Bu}$ görüş, çeşitli açılardan eleştirilebilir. Birincisi halkın, eğer kâdir-i mutlak bir egemense, bir anayasa koymaya da muktedir olduğunun mant1ken kabul edilebilir olduğu gereğidir. Bu önermenin kabulü halinde elde iki seçenek kalır. Ya her nesilde anayasa yeniden ele alınacaktır ya da anayasalarda demokratik usullerle değişiklik yapma kanalları açık bırakılacaktır. Mesele, bu ikisinden hangisinin yerinde olduğudur. Bu durumda bizim de katıldığımız görüşe göre ikincisi daha yerindedir. Öte yandan, demokrasi de basit bir idare tarzı olmasının ötesinde çeşitli değerlere yaslanmaktadır. Bu değerler, siyasi eşitlik ve özgürlük olarak iki başlık altında ele alınabilir. Siyasi eşitliğin ve özgürlüğün kişi ve grup çıkarlarını ilerletmek adına çoğunluklar ve/veya siyasi elitlerce zedelenmesini önleyici önlemler alınması pratik bir ihtiyaç olarak ortaya çıkar. Bu noktada anayasal olmayan rejimlerin demokratik niteliğini koruyamayacağı kabul edilmektedir.

Öte yandan anayasalcılık, toplumun bir birlikte yaşam sözleşmesi olarak siyaset alanını tanzim etmektedir. Bu durum, siyasi bazı meselelerin hukuki alana taşınması ve demokratik yöntemlere ek olarak yargıçlar eliyle çözümü de öngörmesi nedeniyle eleştirilebilmektedir. Elbette politik alanın fazlaca daraltılması, demokrasinin zedelenmesi anlamına gelebilirse de, hem anayasaların demokratik yollarla değiştirilebilir hem de siyasetin hâlâ hukuki alanda belirleyici nitelik taşıyabilir oluşundan ötürü anayasalcılığı kategorik olarak demokrasi dışı bulmak güçtür. Halbuki farklı toplumsal kesimlerin uzlaştırılması yoluyla uyumlu ve istikrarlı bir demokratik idareyi müm- 
kün kılan anayasalcılığın kendisidir. Üstüne üstlük, anayasalar çoğu kez, güçlü demokratik çoğunluklarla kabul edilmekte ve demokratik meşruiyet taşımaktadırlar.

Netice olarak, demokrasi ve anayasalcılık, farklı düşünsel kaynaklardan beslenmekte ve farklı amaçlara yönelmektedir. Bu farklılıklara rağmen her iki kavramın da iyi ve ideal yönetimle ilgilenmesi, bir teması kaçınılmaz kılmaktadır. Bu temas, anayasalcılığın, kaynağı ne olursa olsun iktidarın sınırlanması ideali ekseninde bir çatışmaya dönüşüyor gibi görülebilmektedir. Halbuki anayasalcılığın hak ve özgürlükleri koruyucu işlevi, demokrasinin varlık öncesi ihtiyaçları olan özgürlük ve eşitliği de garanti altına alabilmektedir. Anayasal sistemlerin sahip olacakları demokratik meşruiyetse, bunların devamlılı̆̆ını ve etkinliğini sağlamaktadır. Dolayısıyla sivil topluma duyarlı, esnek bir anayasal sistemle demokrasi çatışmaktan ziyade birbirinin devamlılı̆̆ını sağlar.

Bu konuda değinilmesi gereken son husus, illiberal demokrasi kavramidır. İlliberal demokrasi, kurumsal güvencelerden yoksun otoriter idarelerin 21'inci yüzyıla özgü halidir. Anayasalcılık ve illiberal demokrasi hakkında iki hususa değinilebilir. Birincisi, anayasalcılığın güvencelerinden yoksun "demokratik" bir rejimin ne derecede mümkün yahut arzu edilir nitelikte olduğunun illiberal demokrasilerin varlığı yoluyla ortaya konduğudur. İkincisi, güvence mekanizmalarıyla donatılmış bir anayasalcılı̆̆ın dahi otoriterleşme eğilimlerinin tek başına önüne geçmesinin ne derecede mümkün olduğunun tartışmaya açılabileceğidir. Bu noktada, anayasalcılığın da demokrasi kurallarının da uygulanabilirliğinin ancak toplumların bu yöndeki iradesiyle mümkün olduğunun kabulü gereklidir. 


\section{KAYNAKÇA}

Ackerman, Bruce (1997) "The Rise of World Constitutionalism", Virginia Law Review, Faculty Scholarship Series Paper No: 129, s. 771-797.

Ağaoğulları, Mehmet Ali (2010) Ulus-Devlet ya da Halkın Egemenliği, 2. Baskı, Ankara, İmge Kitabevi Yayınları.

Alexander, Larry 'Constitutionalism', Christiano, Thomas/Christman, Jon (Editörler) (2009) Contemporary Debates in Political Philosophy, 1. Baskı, Malden, MA, Wiley-Blackwell, s. 283-299.

Alexander, Larry (2011) "What are Constitutions, and What Should (and Can) They Do?", Social Philosophy and Policy, C: 28, S: 1, s. 1-24.

Anayurt, Ömer (2018) Anayasa Hukuku: Genel Kısım (Temel İlkeler, Kavram ve Kurumlar), 2. Baskı, Ankara, Seçkin.

Aristoteles (2017) Politika (Çeviren: Akderin, Furkan), 3. Baskı, İstanbul, Say Yayınları.

Bellamy, Richard/Castiglione, Dario (1997) "Constitutionalism and Democracy - Political Theory and the American Constitution”, British Journal of Political Science, C: 27, S: 4, s. 595-618.

Crouch, Colin (2016) Post- Demokrasi, (Çeviren: Zeybekoğlu, A. Emre), 1. Baskı, Ankara, Dost Kitabevi Yayınları.

Dahl, Robert A. (2017) Demokrasi Üzerine (Çeviren: Betül Kadığlu), 4. Baskı, Ankara, Phoenix Yayınevi.

De Tocqueville, Alexis (2012) Amerika'da Demokrasi, (Çeviren: Sertdemir Özdemir, Seçkin) İstanbul, İletişim Yayınları.

Erdoğan, Mustafa (2017) Anayasal Demokrasi, 13. Baskı, Ankara, Siyasal Kitabevi.

Feldman, Jean-Philippe (2010) "La séperation des pouvoirs et le constitutionnalisme. Mythes et réalités d'une doctrine et de ses critiques” Revue française de droit constitutionnel, C: 83, S: 3, s. 483-496.

Friedrich, Carl (2014) Sınırlı Devlet, (Çeviren: Turhan, Mehmet) 2. Baskı, Ankara, Liberte Yayınları.

Fukuyama, Francis (2001) "Natural Rights and Human History", The National Interest, S. 64, s. 19-30.

Ginsburg, Tom/Huq Aziz Z./Versteeg Mila (2018) “The Coming Demise of Liberal Constitutionalism?”, The University of Chicago Law Review, C: 85, S: 2, s. 239-255.

Gosseries, Axel P. (2008) “Constitutions and Future Generations”, The Good Society, C: 17, S: 2, s. 32-37. 
Gönenç, Levent “Ortaçağ Avrupası'nda Anayasacılığın Düşünsel ve Kurumsal Temelleri”, Yazıcı, Serap/Gözler, Kemal/Göztepe, Ece (Editörler) (2008) Ergun Özbudun’a Armağan Cilt II, 1. Baskı, Ankara, Yetkin Yayınevi, s. 267-291.

Gözler, Kemal (2011) Anayasa Hukukunun Genel Teorisi Cilt II, 1. Baskı, Bursa Ekin Basım Yayın Dağıtım.

Gözler, Kemal (1999) Anayasa Hukukunun Metodolojisi 1. Baskı, Bursa, Ekin Kitabevi Yayınları.

Gözler, Kemal (2009) İdare Hukuku Cilt I, 2. Baskı, Bursa, Ekin Kitabevi Yayınları.

Gözler, Kemal (2018) Türk Anayasa Hukuku, 2. Baskı, Bursa, Ekin Basım Yayın Dağıtım.

Huberman, Leo (2014), Feodal Toplumdan Yirminci Yüzyıla, (Çeviren: Belge, Murat), 15. Baskı İstanbul, İletişim Yayınları.

Jobart, Jean-Charles (2006) "La Notion de Constitution chez Aristote", Revue française de droit constitutionnel, C: 65, S: 1, s. 97-143.

Katyal, Neal K. (2001) "Legislative Constitutional Interpration", Duke Law Journal, C: 50, S: 1 , s. 1335-1394.

Kelsen, Hans (2019) Demokrasi: Doğası \& Değeri, (Çeviren: Uysal, Yasin), 1. Baskı, Ankara, Dost Kitabevi Yayınları.

Levy, Jacob T. (2009) "Not so Novus an Ordo Constitutions Without Social Contracts", Political Theory, C: 37, S: 2, s. 191-217.

Levy, Jacob T. “Montesquieu's Constitutional Legacies”, Kingston, Rebecca E. (Editör) Montesquieu and His Legacy (2009), 1. Bask1, State University of New York Press, New York, s. 115-138.

Lijphart, Arend (Tarihsiz Baskı) Çağdaş Demokrasiler, (Çeviren: Özbudun, Ergun/Onulduran, Ersin), Ankara, Yetkin Yayınları.

Madison, James "Federalist No. 48", Carey, George W./McClellan (Editörler) (2001) The Federalist, 2. Baskı, Indiana, Liberty Fund, s. 256-260.

Madison, James "Federalist No. 51", Carey, George W./McClellan (Editörler) (2001) The Federalist, 2. Baskı, Indiana, Liberty Fund, s. 267-272.

Mink, Georges (2016) “L'Europe centrale à l'épreuve de l'autoritarisme”, Politique étrangère, S: 2, s. 89-101.

Montesquieu (2017) Kanunların Ruhu Üzerine (Çeviren: Günen, Berna), 2. Baskı, İstanbul, İş Bankası Kültür Yayınları.

Ober, Josiah (1993) "Public Speech and the Power of the People in Democratic Athens", Political Science and Politics, C: 26, S: 3, s. 481-486.

Özbudun, Ergun (2017) Anayasalcılık ve Demokrasi, 2. Baskı, İstanbul, İstanbul Bilgi Üniversitesi Yayınları. 
Özbudun, Ergun (2018) Türk Anayasa Hukuku, 18. Basım, Ankara, Yetkin Yayınları.

Post, Robert (2005) "Democracy and Equality", Law, Culture and the Humanities, C: 1, S: 2, s. 142-153.

Rancière, Jacques (2018) Nasıl Bir Zamanda Yaşıyoruz?, (Çeviren: Erşen, Murat), 1. Baskı, İstanbul, Metis Yayınları.

Rousseau, Jean-Jacques (2013) Toplum Sözleşmesi (Çeviren: Vedat Günyol), 10. Bask1, İstanbul, Türkiye İş Bankası Kültür Yayınları.

Sartori, Giovanni (1962) "Constitutionalism: A Preliminary Discussion" The American Science Review, C: 56, S: 4, s. 853-864.

Sunstein, Cass Robert "Constitutionalism after the New Deal”, Harvard Law Review, C: 101, S: 2, s. 421-510.

Sweet, Alec Stone (2008) "Constitutionalism, Rights, and Judicial Power", Faculty Scholarship Series, Paper: 77, s. 218-239.

Teziç, Erdoğan (2017) Anayasa Hukuku (Genel Esaslar), 21. Baskı, İstanbul, Beta.

Tremblay, Luc B. (2011) "Deux thèses sur la démocratie et le constitutionnalisme : la souveraineté du peuple et l'engagement préalable", Revue de droit de l'Université de Sherbrooke, C: 41, S: 3, s. 583-605.

Turhan Mehmet (2004) Anayasal Devlet, 3. Baskı, Ankara, Naturel Yayınları.

Turhan, Mehmet (2000) Siyasal Elitler, 2. Baskı, Ankara, Gündoğan Yayınları.

Tushnet, Mark (2003) "Forms of Judicial Review As Expressions of Constitutional Patriotism", Law and Philosophy, S: 22, s. 353-379.

Türe, İlknur (2016) Yeni Anayasacılık Neoliberalizmin Hukuku, 1. Baskı, Pınar Yayınları, İstanbul.

Uygun, Oktay (2017) Demokrasi, 3. Baskı, İstanbul, On İki Levha Yayıncılı.

Waldron, Jeremy (2012) “Constitutionalism: A Skeptical View”, NYU School of Law, Public Law Research Paper No: 10-87, s. 30.

Waldron, Jeremy (1999) Law and Disagreement, 1. Baskı, Oxford University Press, New York, s. 1-45.

Zakaria, Fareed (1997) “The Rise of Illiberal Democracy”, Foreign Affairs, C: 76, S: 6, s. $22-43$.

\section{İnternet Kaynakları}

Dalberg-Acton, Jon, Online Library of Liberty, "Acton-Creighton Correspondance", $<$ https://oll.libertyfund.org/titles/acton-acton-creighton-corres pondence\#lf1524_label_010> s.e.t. 18.03.2019. 
Lincoln, Abraham, Cornell University Rare and Manuscript Collections, "The Gettysburg Adress", <http://rmc.library.cornell.edu/gettysburg/good_cause/transcript.htm>, s.e.t. 19.03.2019.

Merriam-Webster Online Dictionary, <https://www.merriam-webster.com/dictionary/ constitute\# etymology> s.e.t. 12.06.2019.

Jefferson, Thomas, The Papers of Thomas Jefferson, "Thomas Jefferson to James Madison", < < <ttps://jeffersonpapers.princeton.edu/selected-documents/thomasjefferson-james-madison> s.e.t. 18.03.2019.

United States Congress, America's Founding Documents, "Declaration of Independence Transcript", <https://www.archives.gov/founding-docs/ declaration-transcript> s.e.t. 24.03.2019. 